\title{
The pre-Alpine tectonic history of the Austroalpine continental basement in the Valpelline unit (Western Italian Alps)
}

\author{
PAOLA MANZOTTI* $† \&$ MICHELE ZUCALI $\ddagger \S$ \\ *Institut für Geologie, Universität Bern, Baltzerstrasse 1+3, 3012 CH-Bern, Switzerland \\ $\ddagger$ Dipartimento di Scienze della Terra ‘Ardito Desio’, Università degli Studi di Milano, Via Mangiagalli, 3420133 \\ Milano, Italy \\ $\S C N R-I D P A-$ Sezione di Milano, Via Mangiagalli 34 20133, Milano, Italy
}

(Received 28 October 2011; accepted 30 May 2012; first published online 20 August 2012)

\begin{abstract}
The Valpelline unit is a large slice of continental crust constituting the Austroalpine Dent Blanche nappe (NW Italy). The pre-Alpine evolution of this unit holds important clues about the Palaeozoic crustal structure at the northern margin of the Adria continent, about the history of rifting in the Alpine region, and thus about the thermomechanical conditions that preceded the Alpine convergent evolution. Several stages of the deformation history and of partial re-equilibration were identified, combining meso- and micro-structural analyses with thermobarometry. Reconstructed pre-Alpine $P$ $T-t-\mathrm{d}$ paths demonstrate that the Valpelline unit experienced an early stage at pressures between 4.5 and $6.5 \mathrm{kbar}$ followed by migmatite formation. A subsequent stage reached amphibolite to granulite facies conditions. This stage was associated with the development of the most penetrative fabrics affecting all of the Valpelline lithotypes. The pre-Alpine evolution ended with a weak deformation associated with a local mineral-chemical re-equilibration under greenschist facies conditions at $\approx$ $4 \mathrm{kbar}$ and $T<450{ }^{\circ} \mathrm{C}$. A Permo-Mesozoic lithospheric extension is thought to be responsible for asthenosphere upwelling, thereby causing high temperature metamorphism at medium pressure and widespread partial melting, which led to upper crustal magmatic activity.
\end{abstract}

Keywords: Valpelline unit, pre-Alpine metamorphism, Austroalpine, Permian, geodynamic evolution.

\section{Introduction}

Granulite-facies rocks contain a unique record of lithosphere-scale structural and metamorphic history, and granulite terranes reflect major tectonic processes in the deep Earth (Green \& Ringwood, 1967; Bohlen, 1987; Ellis, 1987; Harley, 2008). Granulite-facies rocks and migmatite production are associated with extensional regimes (Pin \& Vielzeuf, 1983; Lardeaux \& Spalla, 1991; Marschall, Kalt \& Hanel, 2003; Schuster \& Stüwe, 2008) as well as with compressional regimes, where they are likely related to crustal shortening, high isotopic heat production and coeval erosional unroofing (Gruf Complex, Central Alps: Galli et al. 2012; e.g. Himalaya: Searle et al. 2010).

A Carboniferous amphibolite to granulite facies evolution is well established in the Variscan belt (Pin \& Vielzeuf, 1983, 1988; Marschall, Kalt \& Hanel, 2003). Slices of these Variscan belt granulites have been incorporated in the Alpine chain within the external or axial units (von Raumer, Stampfli \& Bussy, 2003; Marotta \& Spalla, 2007; Schuster \& Stüwe, 2008). Within the internal units of the Alpine chain, Permian-Triassic magmatism and amphibolitegranulite metamorphism have also been described (Marotta \& Spalla, 2007). There are two main groups of interpretations of this post-Carboniferous thermal anomaly: (i) as an effect of the late orogenic collapse

$\dagger$ Author for correspondence: manzotti@geo.unibe.ch of the Variscan belt (Malavielle et al. 1990; Ledru et al. 2001) and (ii) as a consequence of lithospheric thinning and asthenosphere upwelling that led to continental rifting (Lardeaux \& Spalla, 1991; Diella, Spalla \& Tunesi, 1992; Müntener \& Hermann, 2001; Schuster \& Stüwe, 2008; Marotta, Spalla \& Gosso, 2009).

The aim of the present study is to reconstruct the pre-Alpine tectonometamorphic evolution of the Valpelline unit (Dent Blanche nappe, Western Italian Austroalpine Domain) pre-dating the beginning of the Alpine convergence. The Valpelline unit represents one of these Variscan slices incorporated into the Alpine chain. Rocks from a small side canyon of Valpelline Valley have been selected for this purpose because the pre-Alpine structures and assemblages are well preserved as a result of the poor Alpine deformation affecting this part of the Valpelline unit. Pressuretemperature-time-deformation $(P-T-t-\mathrm{d})$ paths have been derived by combining the sequence of deformational stages with the successive metamorphic imprints. Our results suggest a tectonometamorphic evolution of the Valpelline unit that differs from that described in previous studies.

\section{Geological setting}

The Alps are a double vergent orogen. They formed since the Cretaceous period as a consequence of the convergence between Europe and the Adria-Africa plates and the closure of an oceanic basin, the Tethys, 


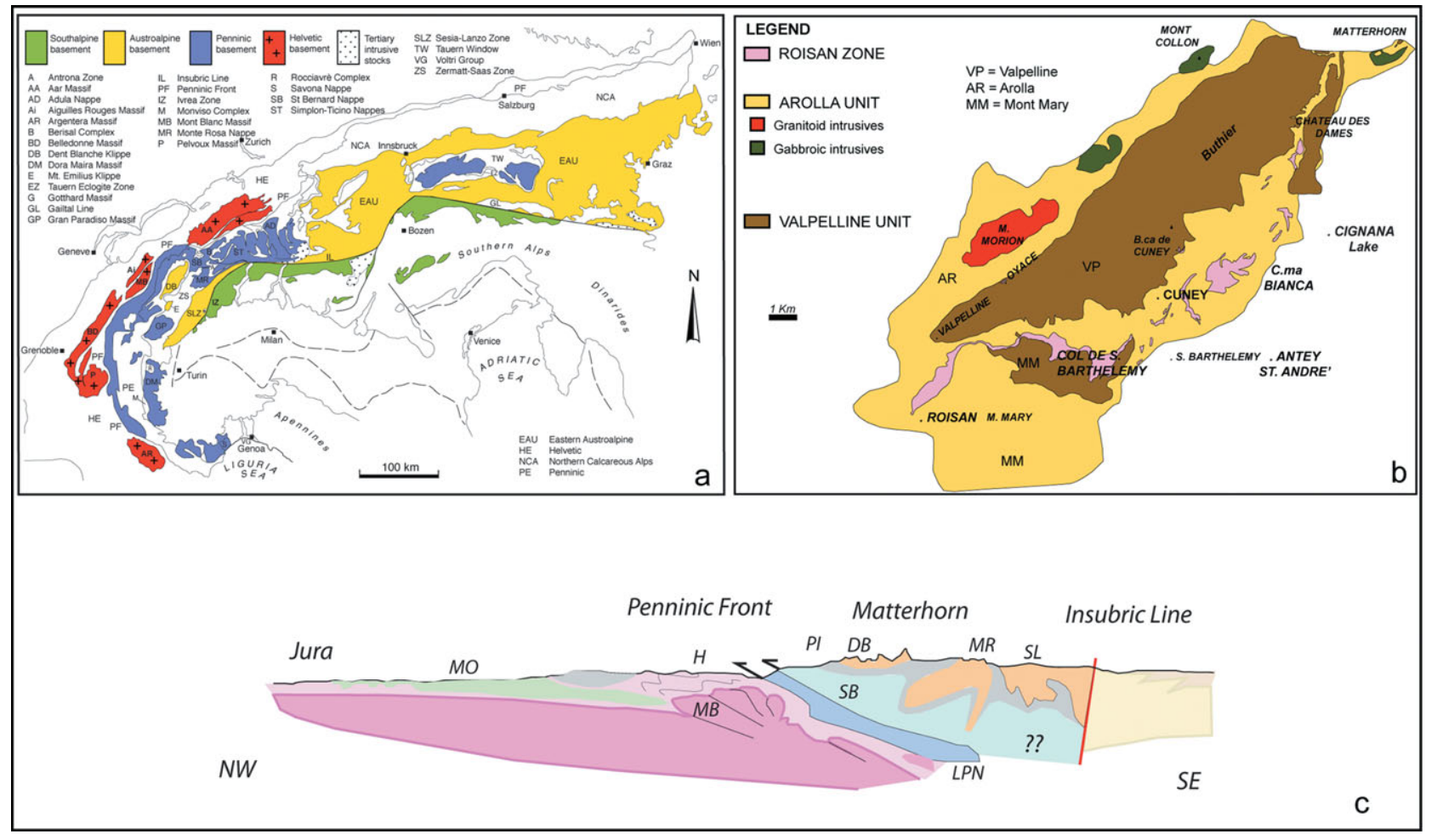

Figure 1. (Colour online) (a) Tectonic map of the Alps (modified after Marotta \& Spalla, 2007). (b) Simplified geological map of the Dent Blanche tectonic system (Roda \& Zucali, 2011). (c) NW-SE geological cross-section along the Western Alps: SL - Sesia-Lanzo Zone; MR - Monte Rosa; DB - Dent Blanche; PI - Penninic; SB - Grand Saint Bernard; MB - Mont Blanc; LPN - Lower Penninic; $\mathrm{H}$ - Helvetic; MO - Molasse (Zucali, 2011).

that was interposed between the two continental passive margins (Malusà et al. 2011). The axial part of the Alps is formed by fragments of continental- and oceanderived rocks, which suffered, from the Cretaceous to Oligocene periods, important vertical and horizontal movements and associated high pressure-low temperature (HP-LT) metamorphism owing to subduction and collision processes (Fig. 1). The continental basement units derived from the Adriatic margin are referred to Austroalpine units. The Dent Blanche nappe (Western Italian Alps) belongs to this domain (Fig. 1). This nappe is composed of pre-Alpine continental crust belonging to the African plate that heterogeneously recorded two tectonic and metamorphic stages of evolution: the preAlpine and the Alpine imprint (Caby, Kienast \& Saliot, 1978; Ballèvre \& Kienast, 1987; Canepa et al. 1990; De Giusti, Dal Piaz \& Massironi, 2003). The former is characterized by superimposed deformation stages associated with high temperature and high to intermediate pressure metamorphic imprints (granulite facies and amphibolite-granulite facies). The Alpine cycle is related to a low temperature and intermediate pressure metamorphic imprint (blueschist-greenschist facies) associated with superimposed mylonitic foliations (Roda \& Zucali, 2008). As classically defined, the Dent Blanche nappe comprises a Palaeozoic basement and lenses of Mesozoic metasedimentary cover (i.e. the Roisan Zone and the Mt Dolin unit). The basement includes the Arolla Series and the Valpelline Series (Argand, 1906; Diehl, Masson \& Stutz, 1952) from since-named units (Manzotti, 2011).
The Arolla unit is mainly composed of Permian-age granite, clinopyroxene-bearing granite, diorite, gabbro metamorphosed and deformed during the Alpine tectonometamorphic evolution to orthogneiss, chloritewhite mica-amphibole-bearing gneiss and schist (De Leo, Biino \& Compagnoni, 1987; Pennacchioni \& Guermani, 1993; Roda \& Zucali, 2008). Within undeformed igneous cores, $1 \mathrm{~m}$ to $10 \mathrm{~m}$ sized xenoliths of biotite-sillimanite-bearing gneisses and amphibolites occur as remnants of pre-Alpine high temperature evolution (Diehl, Masson \& Stutz, 1952; Pennacchioni \& Guermani, 1993; Roda \& Zucali, 2008). The Arolla unit primarily records the Alpine tectonometamorphic evolution, whereas the pre-Alpine imprint is restricted to 1 to $10 \mathrm{~m}$ scale relics. Radiometric determinations on zircons of the Arolla unit orthogneiss indicate an age of $289 \pm 2 \mathrm{Ma}$ for their igneous protoliths (Bussy et al. 1998).

The Valpelline unit comprises pre-Alpine highgrade (amphibolite- to granulite-facies) paragneisses with lenses and layers of basic granulites, garnetclinopyroxene-bearing amphibolites and marbles (Diehl, Masson \& Stutz, 1952; Gardien, Reusser \& Marquer, 1994).

The dominant metamorphic imprint occurs under amphibolite to granulite facies conditions, and it is of pre-Alpine age (Gardien, Reusser \& Marquer, 1994). The Alpine imprint is weak and localized along highstrain zones that are tens to hundreds of metres wide. A static greenschist facies re-equilibration related to the development of an Alpine foliation is observed 
in certain places (Diehl, Masson \& Stutz, 1952; Kienast \& Nicot, 1971; De Leo, Biino \& Compagnoni, 1987; Roda \& Zucali, 2008). Kienast \& Nicot (1971) also described kyanite-chloritoid Alpine assemblages. Hunziker (1974) obtained ages of between 200 and $180 \mathrm{Ma}$ for the Valpelline unit using the $\mathrm{K}-\mathrm{Ar}$ and $\mathrm{Rb}-\mathrm{Sr}$ methods on biotites. An age of $135 \mathrm{Ma}$ has been derived using the $\mathrm{K}-\mathrm{Ar}$ method on muscovites, and this age most likely related to a successive Alpine re-equilibration (Hunziker, 1974; Gardien, Reusser \& Marquer, 1994; Roda \& Zucali, 2008) or may also be interpreted as a mixed age resulting from an incomplete re-equilibration between pre-Alpine and Alpine white micas.

The northeastern part of the Valpelline Valley is characterized by high-grade paragneisses with interlayered basic granulites, Grt-Cpx-bearing amphibolites and marbles (Diehl, Masson \& Stutz, 1952; Gardien, Reusser \& Marquer, 1994). Anatectic veins and dykes of garnet-bearing pegmatite are common (Diehl, Masson \& Stutz, 1952; Pennacchioni \& Guermani, 1993). Low- to medium-grade micaschists with interlayered calc-silicate bands occur in the southwestern part (Pennacchioni \& Guermani, 1993). Metapelites are generally banded, and foliation is defined by the alternation of dark (biotite and garnet) and light (quartz and plagioclase) layers and by the shape preferred orientation (SPO) of biotite and sillimanite (Gardien, Reusser \& Marquer, 1994). Generally, the mineral assemblage of these gneisses consists of garnet, sillimanite, biotite, plagioclase, quartz, rutile, oxide, feldspar, muscovite and cordierite (Diehl, Masson \& Stutz, 1952; Gardien, Reusser \& Marquer, 1994). The lithological boundaries are generally parallel to the dominant foliation, which is marked by biotite and sillimanite in gneiss, amphiboles and plagioclase in amphibolite, and calcite and clinopyroxene in marble. This penetrative foliation can be traced for several kilometres along the valley, making this structure a robust chronological benchmark. This foliation is locally bent: folds that range from metres to decametres in size are tight to isoclinal, and they are often associated with the development of a new axial plane foliation.

Thermobarometrical estimates for the Valpelline unit indicate a first stage at $T=700-800^{\circ} \mathrm{C}$ and $P=9-10$ kbar characterized by the growth of kyanite prior to the migmatite stage at $T=800-850^{\circ} \mathrm{C}$ and $P=6-$ $7 \mathrm{kbar}$, which follows an amphibolite re-equilibration stage at $T=750-800^{\circ} \mathrm{C}$ and $P=5-6 \mathrm{kbar}$ (Gardien, Reusser \& Marquer, 1994). The high temperature pre-Alpine evolution ends with a static stage of reequilibration at $T=650-750^{\circ} \mathrm{C}$ and $P=3-5 \mathrm{kbar}$ (Gardien, Reusser \& Marquer, 1994; Gardien, 1994). Greenschist facies conditions $\left(T=450-500{ }^{\circ} \mathrm{C}, P=\right.$ 3-4 kbar) are recorded in all lithologies but cannot be easily attributed to the pre-Alpine or Alpine cycles (Roda \& Zucali, 2008; Manzotti, 2011). The similar pressure and temperature conditions recorded by the two units suggest that they underwent a comparable polycyclic evolution. At present, the contact between the Valpelline and Arolla units is notably sharp: the transition occurs in a few tens of metres, and it is marked by Alpine-age greenschist-facies mylonites and cataclasites (Pennacchioni \& Guermani, 1993).

We focused our study on rocks cropping out in a small canyon (Fig. 2; UTM WGS84 coordinates: $372874-5077575 ; 373168-5077213$ ), which is $8-10 \mathrm{~m}$ wide and approximately $400 \mathrm{~m}$ long (between $1080 \mathrm{~m}$ and $1300 \mathrm{~m}$ altitude). This canyon is situated on the northern flank of Valpelline Valley between the villages of Valpelline and Oyace, close to Thoules. In this area, the older stages of the structural evolution, pre-dating the dominant foliation, are preserved in metre-scale basic granulite boudins wrapped in migmatites.

\section{Approach and methods used}

Because the geological history of a metamorphic terrane is generally composed of successive or contemporaneous magmatic, metamorphic and deformational evolutionary stages (hereafter simply referred to as stages), we approached the reconstruction of metamorphic terranes by separating each stage on the basis of its characteristics at meso- and microscopic scales following the approach described by Spalla et al. $(2005,2010)$. The relative timing of structures inferred by superimposed fabric elements (Turner \& Weiss, 1963) and the analysis of the mineral assemblages marking each fabric element allow for the definition of the relative timing of structures within each lithology (i.e. phases of deformation, such as $\mathrm{D}_{1}$ and $\mathrm{D}_{2}$ ) with respect to the metamorphic conditions in which they developed.

Criteria for structural correlation among all stages were applied at 1:100 to 1:400 mapping scales (Turner \& Weiss, 1963; Passchier \& Trouw, 2005). Data are represented in a structural-metamorphic map in which lithotypes and fabric elements are highlighted (Fig. 8).

Microstructural analysis was used to identify the metamorphic assemblages, to study the correlation between deformation and metamorphism, and to select areas of special interest to be used for chemical microprobe analyses and $P-T$ calculations. Mineral phases have also been chronologically distinguished (e.g. GrtI, GrtII) using as indicators their microstructural positions, optical characters and relative growth microstructures (Vernon, 2004; Passchier \& Trouw, 2005; Vernon \& Clarke, 2008). In some cases, the relative chronology of the single mineral phases does not correspond to the stage chronology (e.g. GrtII in stage 3), and in large part, this chronology has been validated by the chemical compositions of the mineral phases and by thermobarometrical estimates. Large- and small-scale processes may be linked by combining these different techniques and exploiting the heterogeneous distribution of metamorphism and deformation. The relative chronology of $P-T$ estimates is subsequently used to reconstruct the $P-T-t-\mathrm{d}$ paths, and the tectonometamorphic evolution of the Valpelline 

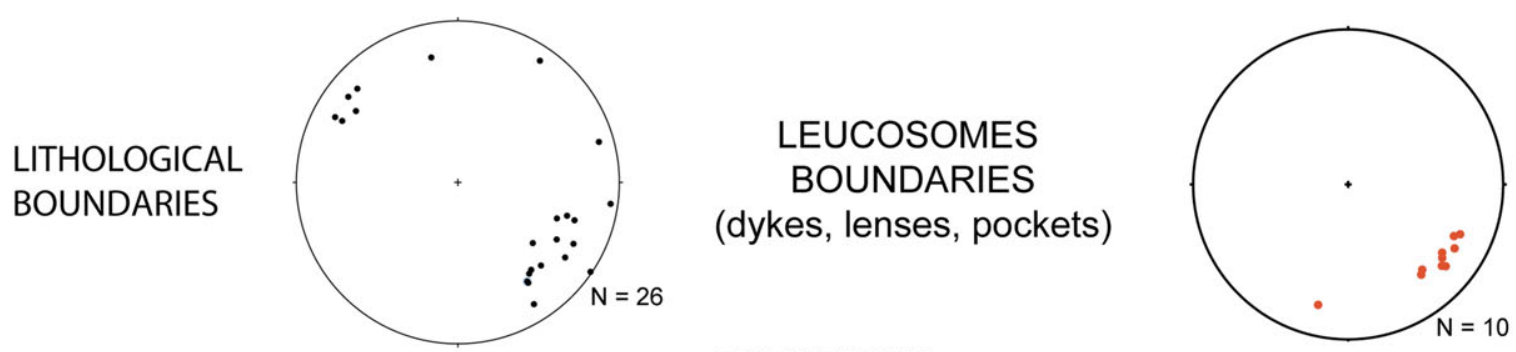

FOLIATIONS

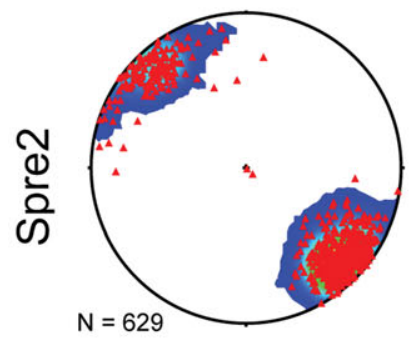

FOLD AXES and AXIAL PLANES

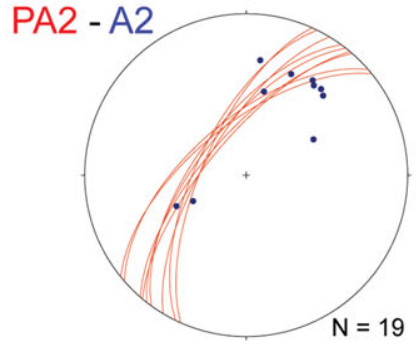

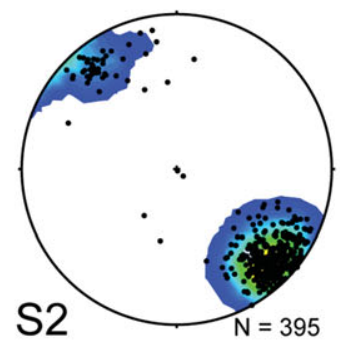

FRACTURES

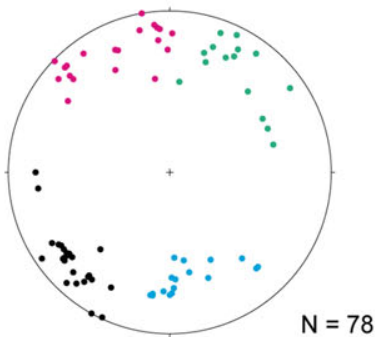

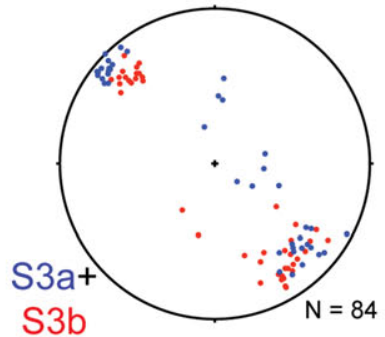

FAULTS

Figure 2. (Colour online) Lower hemisphere Schmidt (equal area) projections of the structures recognized in the studied area.

unit rocks will be presented thereafter in the pre-Alpine tectonic and geodynamic framework.

Mineral abbreviations are in accordance with Whitney \& Evans (2010); in addition, white mica is abbreviated as $\mathrm{Wm}$, and opaque minerals abbreviated as Op.

\section{Meso- and microstructures and their mineral support}

\section{4.a. Rock types and their relationships}

The area is dominated by metapelites (migmatite and Bt-bearing gneiss), metabasites (basic granulite and amphibolite), Ol-bearing marbles and Grt-bearing leucosomes (Fig. 3).

Migmatites (Fig. 3a) consist of metatexites in which leucosomes may occur as centimetre-sized spots; granoblastic aggregates of $\mathrm{Qz}+\mathrm{Kfs}+\mathrm{Pl}+\mathrm{Grt} \pm$ Crd (Fig. 3b) are commonly oriented parallel to the dominant foliations. Locally, the leucosomes may be more prominent and continuous, defining centimetreto metre-thick layers associated with variably thick melanosomes. Melanosomes are generally flat, and the major constituents are Bt, Grt and Sil. Locally, Grt-rich restites occur with a modal amount of $>50-60 \%$. Btbearing gneisses are characterized by fine to medium grains and display a pervasive foliation. Millimetreto centimetre-thick Qz-Fsp lithons are alternated with millimetre-thick Bt films. Locally, Grt-rich layers are also present and are parallel with $\mathrm{Bt}$ films and Qz-Fsp lithons.

Opx-bearing basic granulite and amphibolite occur as metre-scale boudins within migmatite (Fig. 3a, b) or as decametre-scale bodies interlayered with pelitic migmatites and Bt-bearing gneisses. Opx-granulites are characterized by fine to medium grains and show granoblastic texture. These rocks are commonly massive, and a weak foliation marked by the Pland Grt-rich layers is only locally observed at the boundaries of the granulite boudins (Fig. 3a).

Grt-bearing leucosomes (i.e. pegmatites, according to Diehl, Masson \& Stutz, 1952) occur at the boundaries between migmatites and basic boudins (Fig. 3a, c, d).

The mineralogical compositions and the amounts of each mineral in different lithologies are reported in Table 1.

\section{4.b. Stages of evolution}

In the studied area, four evolutionary stages have been recognized at the meso- and micro-scale. The 

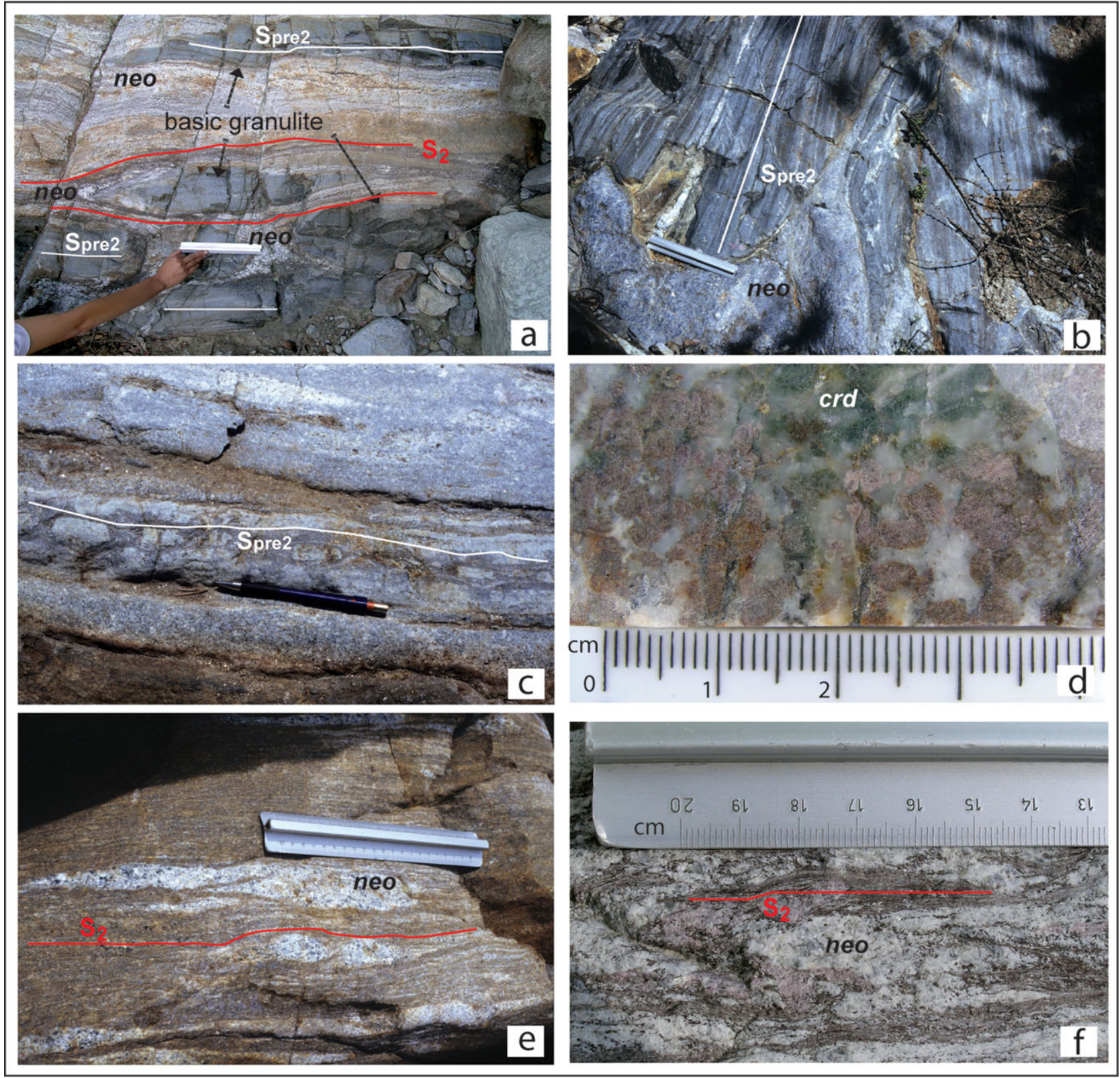

Figure 3. (Colour online) Field photographs of metapelites and metabasites of the Valpelline unit. (a) Opx-bearing basic granulite lens in migmatites. In migmatites proximal to the contact with basic granulite a centimetre-thick Fsp-Grt-rich neosome (neo) occurs. (b) Amphibolite: $\mathrm{S}_{\text {pree }}$ is marked by centimetre-thick layers, respectively, of $\mathrm{Pl}$, black-brown Amp and white-green Amp. A leucosome pocket, associated with stage 2, cuts this structure. (c) Ol-bearing marble layer with a weak $\mathrm{S}_{\text {prez }}$ foliation. (d) Granoblastic aggregate of Qz + Grt + Pl + Crd in a leucosome. (e, f) Migmatites: stage 2 melanosomes and leucosomes alternate. Leucosomes, produced by stage 2, contain Qz, Fsp and locally Grt.

unravelled structural and metamorphic evolution is summarized in the following paragraphs, whereas Table 2 synthesises the superimposed mesostructures and their relative relationships. The orientations of fabric elements are plotted on Schmidt diagrams in Figure 2.

In Figures 4 and 5, the relationships between microstructural evolution and metamorphic growth are summarized. Table 3 reports stable metamorphic assemblages, which are chronologically ordered on the basis of the following microstructural analysis. The subscript associated with each mineral group refers to the relative timing of growth and not to the stages. The map in Figure 8 displays lithological associations and superimposed foliations together with indications of the fabric-supporting minerals.

\section{4.b.1. Stage pre2}

Stage pre 2 is characterized by structures that are clearly prior to stage 2 . This stage is locally recognizable in different lithologies (e.g. boudins of Opx-bearing granulites wrapped within pelitic migmatites (Fig. 3a), amphibolite (Fig. 3b) and Ol-bearing marbles (Fig. 3c)). Stage pre2 likely comprises various events, as locally testified by the different metamorphic assemblages associated with the structures (e.g. amphibole marking a $\mathrm{S}_{\text {pre2 }}$ foliation in amphibolite and orthopyroxene 
Table 1. Mineralogical compositions and amount of each mineral in the different lithologies

\begin{tabular}{|c|c|}
\hline Rock Type & Minerals and \% \\
\hline Pelitic migmatite & $\begin{array}{l}\text { Grt (20), Wm (15), Sil (10-15), Pl (10), Crd (10), Qz (10), } \\
\text { Chl (10), Ep (5-10), Bt (5-10), Rt (5), Ap (5), Cal }(<5), \\
\text { Zrn }(<5), \operatorname{Mnz}(<5)\end{array}$ \\
\hline Bt-bearing gneiss & $\begin{array}{l}\text { Fsp (30-35), Qz (30), Bt (15-20), Grt (10-15), Rt }(<5) \text {, } \\
\quad \operatorname{Zrn}(<5), \operatorname{Mnz}(<5)\end{array}$ \\
\hline $\begin{array}{l}\text { Zrnx-bearing basic } \\
\text { granulite }\end{array}$ & $\begin{array}{l}\text { Cpx (15), Zrnx (15), Pl (20), Am (10), Bt (5-10), Zrn (5), } \\
\text { Wm (5), Chl (<5), Tur (<5) }\end{array}$ \\
\hline Amphibolite & $\begin{array}{l}\text { Brown Am (25-30), Pl (15-20), Grt (15), Wm (15) } \\
\text { white-green Am (10-20), Chl (5-10), Ep (5-10), Zrn (5), } \\
\text { Qz }(<5), \operatorname{Ap}(<5)\end{array}$ \\
\hline Ol-bearing marble & $\begin{array}{l}\mathrm{Cal}(40-50), \mathrm{Qz}(5-10), \mathrm{Wm}(5-10), \mathrm{Ol}(5-10), \operatorname{Srp}(0-5), \\
\quad \operatorname{Grt}(0-5), \operatorname{Px}(0-5), \mathrm{Chl}(0-5), \mathrm{Ep}(0-5)\end{array}$ \\
\hline Grt-bearing leucosome & $\begin{array}{l}\mathrm{Pl}(20), \operatorname{Kfs}(20), \mathrm{Qz}(15), \mathrm{Wm}(15), \mathrm{Bt}(10), \mathrm{Grt}(5-10), \mathrm{Chl} \\
\quad(5-10), \operatorname{Ep}(5), \mathrm{Zrn}(<5), \mathrm{Mnz}(<5)\end{array}$ \\
\hline
\end{tabular}

Table 2. Schematic relationships between deformation and metamorphism in the Valpelline Unit

\begin{tabular}{|c|c|c|c|c|}
\hline \multicolumn{5}{|c|}{ Relative chronology of mesostructures and their mineral support } \\
\hline Stage & Events & Age & Structures & Mineral associations \\
\hline pre2 & Met-pre2+D-pre2 & Pre-Alpine & Inequigranular aggregates; $\mathrm{S}_{\text {pre2 }}$ & $\begin{array}{l}\text { Opx-Cpx-Pl (basic granulite); amphibolite, } \\
\text { Ol-bearing marble }\end{array}$ \\
\hline 2 & Met2+Mag2+D2 & Pre-Alpine & $\begin{array}{l}\text { Metric migmatite structures }\left(\mathrm{S}_{2}\right) \text {; reaction rims } \\
\text { at basic boudin boundaries }\end{array}$ & $\begin{array}{l}\text { Sil-Bt-Grt melanosome and } \\
\text { Qz-Pl-Kfs-Grt-Bt } \pm \text { Crd leucosome } \\
\text { Opx-Cpx-Pl } \pm \text { Amp } \pm \text { Grt (basic granulite) } \\
\text { Qz-Pl-Kfs-Grt-Bt leucosome }\end{array}$ \\
\hline 3 & $\begin{array}{l}\text { Met3a+D3a } \\
\text { Met3b+D3b }\end{array}$ & Pre-Alpine & $\begin{array}{l}\text { Folds and foliations }\left(\mathrm{S}_{3 \mathrm{a}}\right) \\
\text { Folds and foliations }\left(\mathrm{S}_{3 \mathrm{~b}} ; \mathrm{F}_{3 \mathrm{~b}} ; \mathrm{AP}_{3 \mathrm{~b}} \mathrm{~L}_{3 \mathrm{~b}}\right)\end{array}$ & $\begin{array}{l}\text { Bt-Kfs-Qz-Sil-Grt; Am-Pl } \\
\text { Bt-Kfs-Qz-Sil-Grt } \\
\text { Am-Pl } \\
\text { Cc-Ol-Phl-Cpx }\end{array}$ \\
\hline & Mag3 & & Intrusive boundaries & Leucosome or lenticular intrusions \\
\hline 4 & Met4 + D4 & Alpine & $\begin{array}{l}\text { Coronas } \\
\text { Fracture, faults and veins }\end{array}$ & $\begin{array}{l}\text { Static growth of Chl, Wm, Ep } \\
\text { Chl-Ep-rich veins }\end{array}$ \\
\hline
\end{tabular}

Met - metamorphic; D - deformational; Mag - magmatic.

$\mathrm{S}$ - foliation; L - lineation; $\mathrm{F}$ - fold; AP - axial plane.

layers developing in basic granulite). For this reason, we only refer to stage pre2 in reference to all structures pre-dating stage 2 . Parts a-c and e of Figure 3 show the geometric overprinting relationships between stage 2 structures (e.g. $\mathrm{S}_{2}$ foliation, boudinage and melt pocket) and those pre-dating them.

4.b.1.a. Meso-scale observations

$\mathrm{D}_{\text {pre2 }}$ structures are more evident in Opx-bearing granulite boudins, amphibolites and marbles and mainly consist of a weak centimetre- to millimetrethick $\mathrm{S}_{\text {pre2 }}$ foliation. $\mathrm{S}_{\text {pre2 }}$ in granulites are rare; where present, they are marked by a gentle SPO of Pl, Cpx and Opx.

In amphibolites, the $\mathrm{S}_{\text {pre2 }}$ foliation is defined by centimetre-thick mineralogical layers alternating between Amp- and Pl-rich. The SPO of Amp also defines this structure (Fig. 3b).

4.b.1.b. Micro-scale observations

In basic granulites, an inequigranular polygonal to interlobate texture is preserved. It is characterized by subhedral crystals of OpI, BtI and ApI and by clustered polygonal to interlobate aggregates of PII, CpxI and
OpxI (Fig. 4a). Euhedral to subhedral OpxI and CpxI are commonly prismatic in shape, ranging from millimetres to centimetres in size with well-defined and straight grain boundaries. BtI occurs as single grains $(0.5-1 \mathrm{~mm})$ and locally shows undulose extinction. OpI and ApI occur as millimetre-sized single crystals in close association with OpxI, CpxI and PII.

In Bt-gneisses, stage pre 2 is also preserved; it occurs within metre-sized volumes where aggregates of QzI + PlI + KfsI + BtI + GrtI \pm SilI are recognizable. QzI occurs as strained grains or aggregates with undulose extinction and deformation bends. PII shows a prismatic anhedral to subhedral habit up to several millimetres in size, and it is characterized by deformational features such as undulose extinction and deformation twinning. QzI and PII form microlithon domains that are elongated to BtI aggregates. BtI and rarely SilI form microfilm domains. GrtI crystals are wrapped by the main foliation marked by the SPO of $\mathrm{BtI} \pm$ SilI and by QzI elongate aggregates. GrtI occurs as millimetre-sized euhedral grains with inclusions of Qz and BtI (Fig. 4b). ZrnI is commonly found as euhedral prismatic crystals with high relief and 

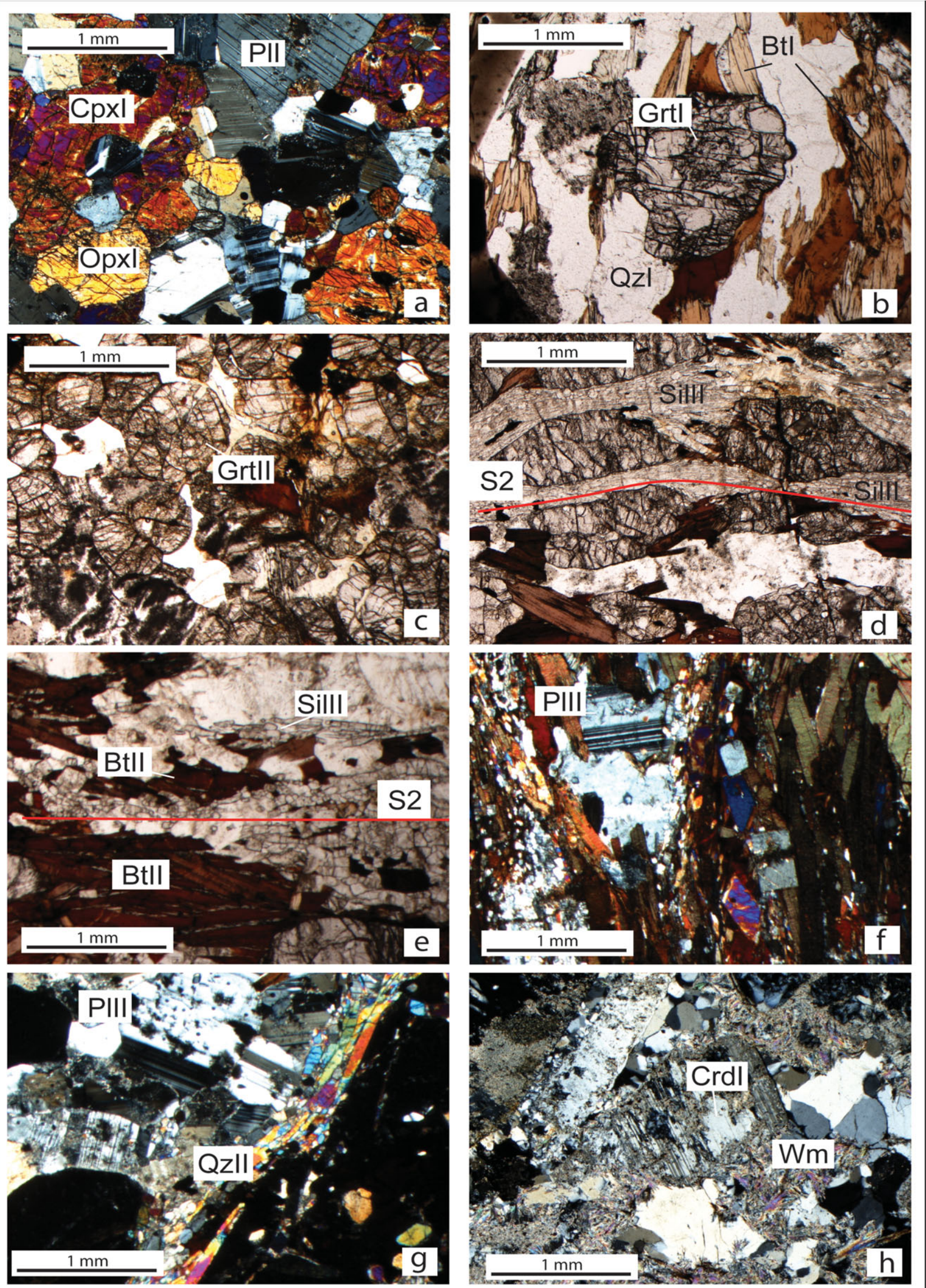

Figure 4. (Colour online) Photomicrographs of observed microstructures of metapelites and metabasites of the Valpelline unit. (a) Basic granulite: polygonal to interlobate aggregate of CpxI, OpxI and PII (crossed polars). (b) Bt-bearing gneiss: GrtI occurs as an inclusion-rich core within the $S_{\text {pre2 }}$ foliation (plane-polarized light). (c) Pelitic migmatite: millimetre-sized rounded grains of GrtII in a melanosome (plane-polarized light). (d) Pelitic migmatite: aggregates of large fibrolitic SillI partly truncate GrtII rims and define the 


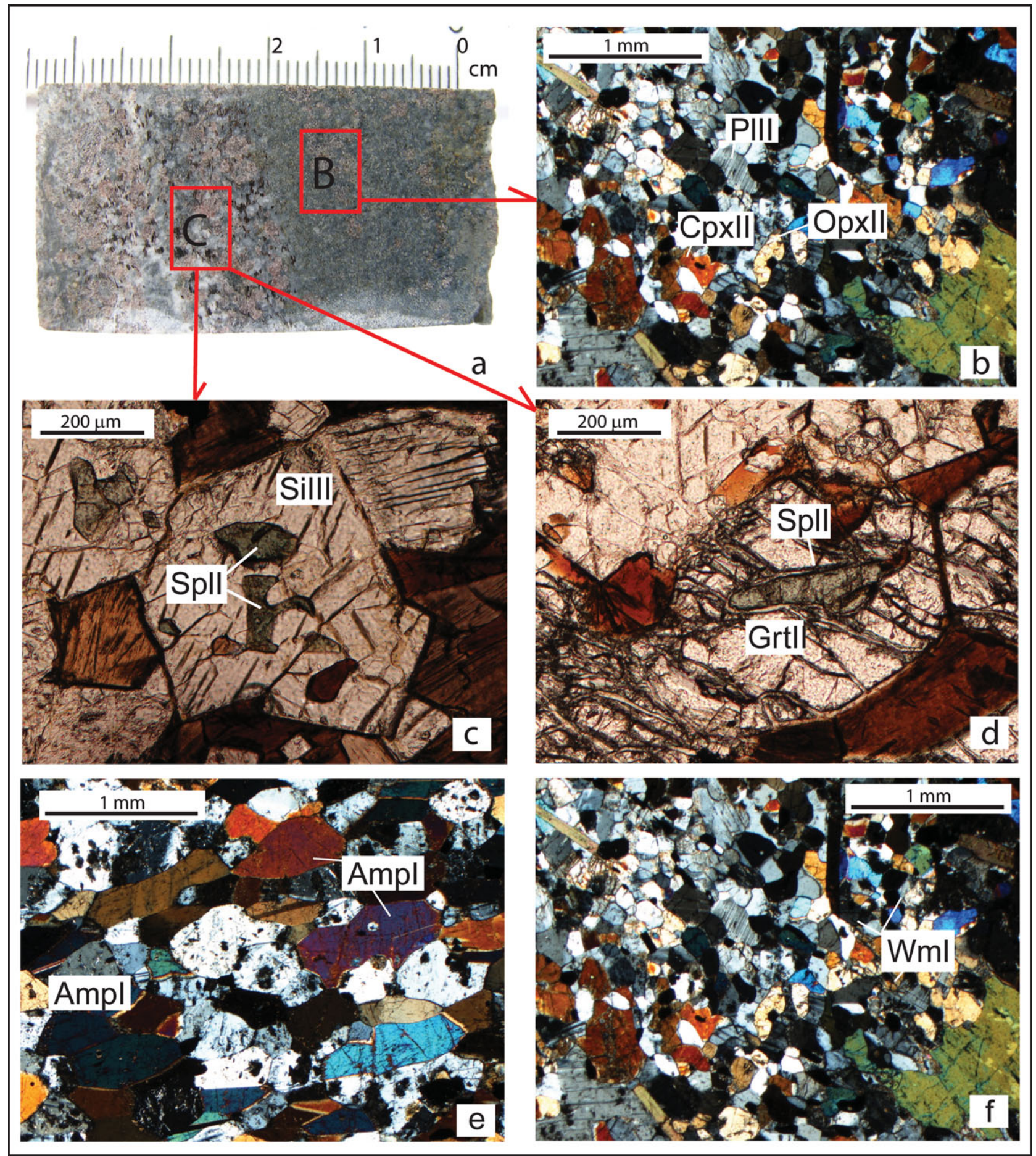

Figure 5. (Colour online) (a) Contact (C) between pelitic migmatite and a lens of basic granulite (B). (b) Basic granulite at the contact with migmatite: interlobate aggregate of OpxII + CpxII + PIII (crossed polars). (c, d) Pelitic migmatite at the contact with basic granulite: SplI + GrtII and SplI + SilII aggregates (plane-polarized light). (e) Amphibolite: shape preferred orientation of AmpI defines the $\mathrm{S}_{3 \mathrm{a}}$ foliation (crossed polars). (f) Pelitic migmatite: Grt porphyroblasts with WmI-filled fractures (crossed polars).

birefringence, and they are frequently associated with GrtI. MnzI occurs as rounded, high-relief crystals with high birefringence associated with SilI or as inclusions in GrtI and BtI.
Therefore, the association of BtI + QzI + PlI $+\mathrm{KfsI}+\mathrm{GrtI}+\mathrm{ZrnI}+\mathrm{MnzI}+\mathrm{RtI}+\mathrm{ApI} \pm$ Sill defines the relict $S_{\text {pre2 }}$ foliation in metapelites (Table 3).

$\mathrm{S}_{2}$ foliation (plane-polarized light). (e) Pelitic migmatite: SillI aggregates partly replace BtII (plane-polarized light). (f) Pelitic migmatite: subhedral crystal of PIII with growth twins (crossed polars). (g) Pelitic migmatite: leucosome with a coarse-grained granoblastic texture, characterized by PIII, KfsII and QzII (crossed polars). (h) Pelitic migmatite: CrdI crystals are replaced by aggregates of Wm (crossed polars). 
Table 3. Pre-Alpine and Alpine deformational, magmatic and metamorphic events (D, Mag, Met) of the Valpelline rocks, recognized at the microscale. Metamorphic assemblages marking each fabric are also described

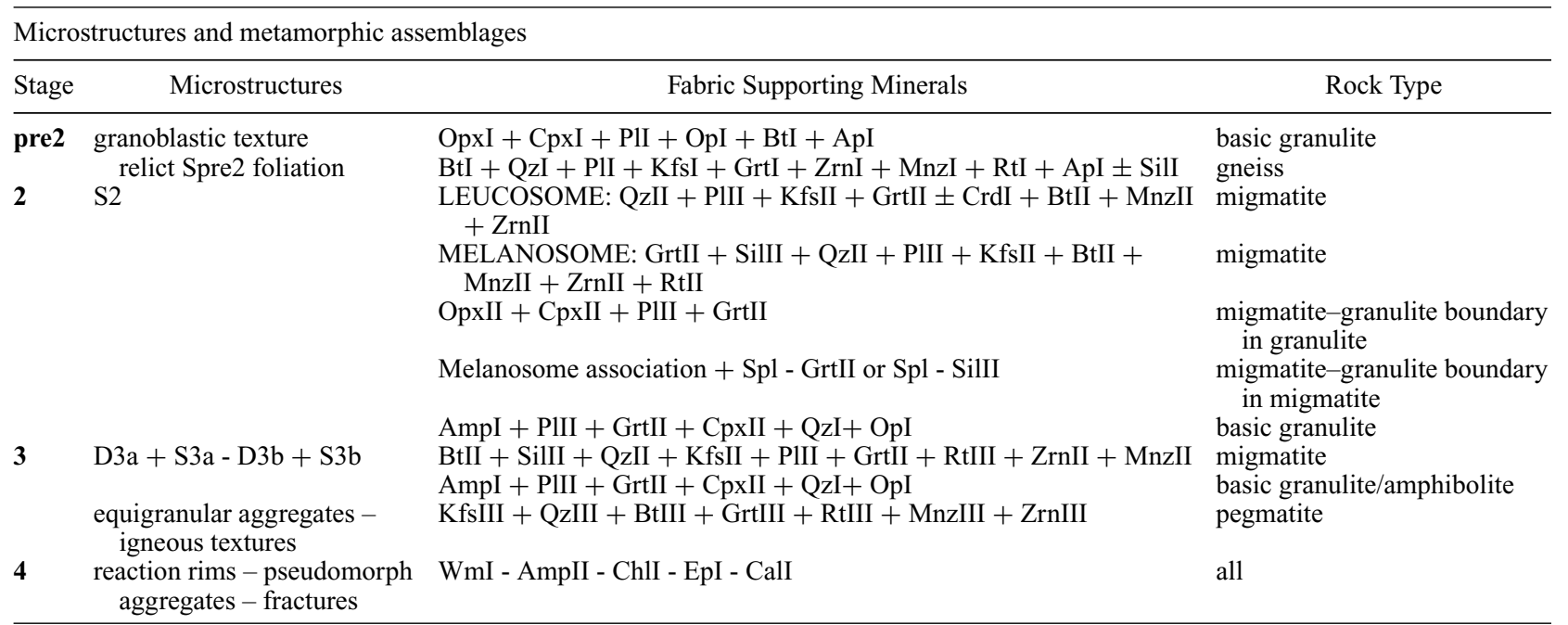

\section{4.b.2. Stage 2}

During stage 2, migmatite fabrics develop in metapelites. Contemporaneously, basic granulites and amphibolites partly or completely change their mineral associations; such reactions are localized at the basic boudin boundaries where stage 2 neosomes localize (Fig. 3a; Table 2). This stage is not recorded in marbles, whereas it is maximally developed in metapelites.

\section{4.b.2.a. Meso-scale observations}

In pelitic migmatite, $\mathrm{D}_{2}$ structures consist of centimetre- to millimetre-thick $\mathrm{S}_{2}$ foliation, expressed by alternating layers of leucosomes (Fig. 3d) and melanosomes (Figs 3e, f). The leucosomes are disharmonically folded and boudined in the fold limbs. The leucosomes hold their granoblastic structure, even where folded during $\mathrm{D}_{2}$. The melanosomes are variable in width and are composed of Sil, Grt, Bt, Pl and Kfs. The SPOs of Sil and flattened Grt layers define the $S_{2}$ foliation in melanosomes together with the SPO of $\mathrm{Bt}$ (Fig. 3f). Marble, amphibolite and granulite boudins are wrapped by the $S_{2}$ foliation at decimetre to metre scales. Centimetre-thick leucosomes are also localized along the boundaries between granulite-amphibolite boudins and migmatites (Figs 3a, b). These boundaries are usually parallel to the $S_{2}$ foliation that it is marked by $\mathrm{Bt}+$ Sil-rich layers in migmatites and by the increase in the amount of Grt and Amp within granulite and amphibolite boudins. In amphibolite boudins, $\mathrm{S}_{\text {pre2 }}$ foliation generally tends to be folded and parallel to the external $S_{2}$ foliation, especially at their margins, as is also shown by stereographic projection in Figure 2.

\section{4.b.2.b. Micro-scale observations}

In pelitic migmatite, melanosomes and leucosomes are easily distinguished by their textures: leucosomes are defined by granoblastic polygonal aggregates of QzII + PIII + KfsII + GrtII + BtII, whereas melanosomes preserve a spaced foliation marked by the SPO of BtII + QzII + GrtI/II + SilII. At the micro-scale, the distinctive character of the melanosomes is the high modal proportion of residual and accessory minerals, such as Grt and Sil. GrtII occurs as millimetre- to centimetre-sized grains, locally zoned (Fig. 4c); the inner part (i.e. GrtI) is rich in inclusions of RtI, QzI, BtI and SilI, whereas the outer part (GrtII) is inclusionfree. Large and rounded inclusions of QzI and BtI are common in GrtI, as are aggregates of BtI + SilI; such relationships may be interpreted as the relics of the older reactant assemblage (Sawyer, 2008; Kriegsman \& Alvarez-Valero, 2010). The rims of GrtII may be partly truncated or dissolved by aggregates of large, fibrolitic SilII (Fig. 4d). $\mathrm{S}_{2}$ foliation, marked by the SPO of SilII, BtII and minor QzII, KfsII and PIII, is generally well developed in melanosomes. BtII has a more homogeneous appearance than BtI: it is more reddish in colour and commonly is not internally strained. BtII may be partly replaced by SilII (Fig. 4e). SilII occurs as prismatic porphyroblasts or as elongate fibrolitic domains defining $\mathrm{S}_{2}$ foliation (Fig. 4e). Euhedral crystals of SilII may occur in association with GrtII rims and BtII and indicate a likely reaction involving SilII as a product of GrtII and BtII. This reaction is also suggested by the presence of SilII aggregates, generally parallel to $S_{2}$ foliation, at the rims of GrtII; these microstructural relationships are commonly found in melanosomes close to leucosomes containing microstructures that indicate crystallization from melt (see below). PIII (0.5-6 mm) forms subhedral or anhedral crystals, and many of them show growth twins (Fig. 4f), suggesting growth from melt (Vernon, 2004; Sawyer, 2008), whereas few grains are characterized by undulose extinction, deformation bands and twins. RtII may occur as millimetre-sized single crystals or as inclusions within BtI and BtII. ZrnII and MnzII are also enclosed within QzII and SillI.

Leucosomes display coarse-grained granoblastic textures; PIII, KfsII and QzII constitute the main frame of the texture (Fig. $4 \mathrm{~g}$ ). The interstitial space 
is filled by QzII, KfsII and BtII, thereby defining thin films. GrtII and BtII crystals that occur in the leucosome are relatively strain-free euhedral grains. Locally, millimetre-sized CrdI porphyroblasts occur, but they have generally been replaced by aggregates of Wm (Fig. 4h). MnzII and ZrnII occur in association with QzII, BtII and GrtII.

Consequently, the assemblages marking the fabrics developed during stage 2 and thus interpreted as stable during this stage are as follows (Table 3):

$$
\begin{aligned}
& \text { Melanosomes: GrtII + SilII }+Q z I I+P l I I+K f s I I \\
& \quad+\text { BtII }+ \text { MnzII }+Z r n I I+R t I I \\
& \text { Leucosomes: } Q z I I+P l I I+K f s I I+G r t I I \pm C r d I \\
& \quad+\text { BtII }+M n z I I+Z r n I I
\end{aligned}
$$

Marble, amphibolite and granulite boudins are wrapped by the $S_{2}$ foliation at decimetre to metre scales. Centimetre-thick leucosomes are also localized along the boundaries between granulite-amphibolite boudins and migmatites (Fig. 3a, b). These boundaries are usually parallel to the $\mathrm{S}_{2}$ foliation that it is marked by $\mathrm{Bt}+$ Sil-rich layers in migmatites and by the increase in the amount of Grt and Amp within granulite and amphibolite boudins. In amphibolite boudins, $\mathrm{S}_{\text {prez }}$ foliation generally tends to be folded and parallel to the external $S_{2}$ foliation, especially at their margins (Fig. 3e), as is also shown by stereographic projection in Figure 2.

Stage 2 is also recorded at the contact between migmatites and lenses of basic granulites (Fig. 5a). The recrystallization of $\mathrm{Opx}, \mathrm{Cpx}$ and $\mathrm{Pl}$ occurs in basic granulite, developing OpxII + CpxII + PIII + GrtI polygonal or interlobate inequigranular aggregates (Fig. 5b). In the central portions of basic granulite, $\mathrm{S}_{2}$ is expressed by the SPO of Amp and by Pl layers. In the corresponding migmatite, $\mathrm{S}_{2}$ is a spaced foliation marked by GrtII-rich bands alternating with PIII-QzII-rich layers. The SPO of BtII also marks this structure. PIII crystals $(2-6 \mathrm{~mm})$ show growth and deformation twins, and the grain boundaries are straight and rational. BtII grains are generally euhedral and define Bt-rich layers that commonly rim GrtII bands and PIII-QzII layers. Spl + GrtII and $\mathrm{Spl}+$ SilII aggregates may locally occur (Fig. 5c, d). Spl is found as anhedral crystals $(0.5-2 \mathrm{~mm})$ with amoeboid grain boundaries.

\section{4.b.3. Stage 3}

Stage 3 is characterized by two superimposed deformational phases that rework the pre-existing structures. Both deformational phases are marked by the same metamorphic minerals, thereby supporting the decision to group them into a single stage.

\section{4.b.3.a. Meso-scale observations}

During stage $D_{3 a}$, the $S_{2}$ foliation is folded, and a new axial plane foliation $S_{3 a}$ develops. In migmatites, $\mathrm{S}_{3 \mathrm{a}}$ is marked by the SPO of Bt and Sil aggregates, which are associated with Grt grains and are frequently elongated parallel to this structure. In granulites, $\mathrm{S}_{3 \mathrm{a}}$ is marked by dark, centimetre-thick Amp $\pm \mathrm{Bt}$ layers and light, millimetre- to centimetre-thick PlCpx layers. In amphibolites, $\mathrm{S}_{3 \mathrm{a}}$ is expressed by alternating millimetre- to centimetre-thick Pl- and Amp-rich layers. In certain cases, $\mathrm{S}_{3 \mathrm{a}}$ is also marked by the SPO of Amp and by layers and lenses constituted by Grt and green-grey Cpx. In marbles, the SPO of carbonate and locally Qz- and Cpx-rich layers usually define this fabric. The orientation of the $\mathrm{S}_{3 \mathrm{a}}$ foliation is generally settled in an area of $25-30 \mathrm{~km}^{2}$ and is roughly parallel to the lithological boundaries (see the stereographic projections in Fig. 2).

Stage $D_{3 b}$ is associated with close to isoclinal folds in all lithotypes. In migmatites and amphibolites, the $\mathrm{D}_{3 \mathrm{~b}}$ deformation phase may be locally associated with the development of a new axial plane foliation, $S_{3 b}$, which is visible at the decametre to metre scale. Generally, $\mathrm{S}_{3 \mathrm{a}}$ and $S_{3 b}$ are marked by the same minerals, and they may be easily recognized only where superimposed relationships are preserved. Associated with this phase of deformation, centimetre- to metre-thick $\mathrm{Bt}+$ Grt-bearing leucosomes occur, cross-cutting lithological boundaries and $S_{2}, S_{3 a}$ and $S_{3 b}$ foliations or locally parallel to $\mathrm{S}_{3 \mathrm{a}}$ or $\mathrm{S}_{3 \mathrm{~b}}$ structures. Such geometrical relationships suggest a development during the final stage of $\mathrm{D}_{3}$.

4.b.3.b. Micro-scale observations

$\mathrm{D}_{3 \mathrm{a}}$ structures are well recorded in migmatites. $\mathrm{S}_{3 \mathrm{a}}$ is a spaced foliation marked by BtII + GrtII layers and by QzII + PIII + KfsII lithons. BtII occurs as euhedral crystals with straight and well-defined grain boundaries. QzII occurs as millimetre- to centimetresized crystals with undulose extinction. $\mathrm{S}_{3 \mathrm{a}}$ is also marked by the SPOs of BtII and SilII; SilII forms elongate crystals $(0.2-10 \mathrm{~mm})$ with straight and sharp grain boundaries or elongate, fibrolitic domains.

In metabasites, $\mathrm{S}_{3 \mathrm{a}}$ is marked by $\mathrm{Pl}+\mathrm{Qz}$ and by AmpI \pm GrtII layers. Pl (PII and PlII) occurs as subhedral crystals in association with CpxII, locally displaying wavy extinction and deformation twins. AmpI is found as elongated or rhomboid crystals $(1-9 \mathrm{~mm})$ that are brown or pale green in colour (Fig. 5e).

Syn-stage 3 leucosomes are defined by the association KfsIII + QzIII + BtIII + GrtIII + RtIII + MnzIII + ZrnIII. Leucosomes display equigranular size distribution with a polygonal shape. BtIII, KfsIII and GrtIII $(2-20 \mathrm{~mm})$ have idiomorphic shapes. QzIII has an anhedral shape; the grain size varies from less than $0.5 \mathrm{~mm}$ to $1.5 \mathrm{~cm}$. Crystals frequently show undulose extinction, indicating that local deformation occurred after the intrusion. MnzIII and ZrnII occur as millimetre-sized grains with a euhedral shape associated with QzIII, GrtIII and BtIII.

\section{4.b.4. Stage 4}

Stage 4 is not perceivable at the scale of the Valpelline unit, and it is generally associated with the static 
growth of $\mathrm{Chl}$ and $\mathrm{Wm}$ in migmatites and by the static replacement of Pl by Ep and Wm in basic granulites. At the valley scale, a millimetre-thick foliation $\left(\mathrm{S}_{4}\right)$ locally develops; this foliation is marked by $\mathrm{Wm}$ and $\mathrm{Chl}$ and may be also mylonitic (Pennacchioni \& Guermani, 1993; Roda \& Zucali, 2008). In the studied area, this structure does not develop, but $\mathrm{Chl}$ and $\mathrm{Wm}$ statically overgrow the old foliations. The late stage 4 is also characterized by the development of brittle, metre-scale structures as faults and cataclasites.

Chl and Ep may also be found as seals of brittle faults. In these zones, faults and fracture systems produce the disaggregation of the protoliths and the loss of the primary mineralogical and fabric characters.

\section{4.b.4.a. Meso-scale observations}

The $\mathrm{S}_{4}$ foliation is marked by greenschist-facies minerals in all rock types. In metapelites, this foliation is expressed by $\mathrm{Wm}$ and $\mathrm{Chl}$ SPOs; in amphibolite, by green Amp SPO; and in marble, by $\mathrm{Chl}$ and $\mathrm{Cal}$ SPOs. This deformation phase is not homogeneously distributed within the Valpelline unit because it is localized along metres- to tens-of-metres-thick bands, particularly at the contact between the Arolla and the Valpelline units (Pennacchioni \& Guermani, 1993). $\mathrm{S}_{4}$ foliation is parallel to the contact between the Arolla and Valpelline units, and it is subsequently folded by recumbent folds.

\section{4.b.4.b. Micro-scale observations}

In metapelites, WmI fine-grained aggregates and irregularly shaped aggregates of EpI partly or completely replace PII, KfsI, SilI and SilII. ChlI aggregates and finegrained WmI partly replace all generations of Grt and Bt. Grt porphyroblasts contain WmI- and ChlI-filled fractures (Fig. 5f). ChlI (0.5-3 mm) also forms elongate aggregates in which crystals frequently show wavy extinction. CalI occurs as anhedral grains $(0.5-2 \mathrm{~mm})$ with lobate and well-defined grain boundaries.

In metabasites, pale green AmpII partly or completely replaces CpxI, OpxI and AmpI. ChlI aggregates and fine-grained WmI partly replace AmpI and GrtI. WmI fine-grained aggregates and irregularly shaped aggregates of EpI partly or completely replace PII and PIII. These newly formed minerals may grow along fractures.

\section{Mineral chemistry}

Minerals were analysed with an electron microprobe (EMPA: JEOL 8200 Super Probe) and a scanning electron microscope (SEM: Cambridge Stereoscan 360 ISIS 300 Oxford) at the Dipartimento di Scienze della Terra 'A. Desio' - Università degli Studi di Milano. The operating conditions were $20 \mathrm{kV}$ accelerating voltage, a filament intensity of $1.70 \mathrm{~A}$ and a probe intensity of $280 \mathrm{pA}$ for EMPA and $15 \mathrm{kV}$ accelerating voltage and a sample current of $190 \mathrm{pA}$ for SEM. Natural silicates were used as standards; matrix corrections were calculated with the ZAF procedure. Representative mineral compositions are reported in the online Supplementary
Material available at http://journals.cambridge.org/geo (Tables S1a-g). Figure 6 shows chemical variations within selected mineral phases with respect to their microdomain occupancy and evolutionary stage. Mineral formulae have been recalculated using JPT (Zucali, 2005), which uses the general recalculation scheme after Deer, Howie \& Zussman (1996).

Biotite. Biotite in gneiss and migmatite commonly coexists with ilmenite and shows a linear increase in Ti content from BtI to BtII. Ti content in BtI ranges from 0.342 to 0.798 atoms per formula unit (a.p.f.u.), and it is between 0 and 1 a.p.f.u. in BtII. Among BtII, it is also possible to separate low-Ti minerals from those with high to very high Ti content (Fig. 6). $\mathrm{X}_{\mathrm{Mg}}$ varies from 0.40 to 0.80 in both $\mathrm{BtI}$ and $\mathrm{BtII}$. $\mathrm{Al}^{\mathrm{VI}}$ content also varies from 0 to 1 , and it is closely related with the Ti content variations, as suggested by various studies (Scheurs, 1985; Henry, Guidotti \& Thomson, 2005). In metabasite (basic granulite and amphibolite), Bt compositions are generally homogeneous: Ti content varies from 0.52 to 0.72 a.p.f.u., $\mathrm{Al}^{\mathrm{VI}}$ from 0 to 0.184 a.p.f.u., and $\mathrm{X}_{\mathrm{Mg}}$ from 0.52 to 0.65 .

Amphibole. In metabasites, AmpI (stages 2 and 3) shows a $\mathrm{Ca}$ content between 1.5 and 3.5 a.p.f.u., whereas $\mathrm{Si}$ varies between 6.71 and 6.71 a.p.f.u. $\mathrm{Ti}$ content varies from 1.40 to 3.20 a.p.f.u. In metabasites (stage 3), AmpII displays an Si content between 7 and 8 a.p.f.u., whereas Ti varies between 0 and 1.0 a.p.f.u.

Garnet. GrtI and GrtII in metapelites are Fe-rich (1.68-2.00 a.p.f.u.) with a high $\mathrm{Mg}$ content (0.76-1.09 a.p.f.u.) and lower contents of $\mathrm{Ca}(0.08-0.48$ a.p.f.u.) and Mn (0.02-0.06 a.p.f.u.). The Alm content ranges from 59 to $67 \%$, whereas the Py content varies from 27 to $37 \%$. GrtII rims commonly show an increase in the $\mathrm{Mg}$ and $\mathrm{Ca}$ contents compared with GrtI cores.

GrtI (stage 2) in basic granulites and amphibolites shows a Ca content varying from $0.43-0.60$ a.p.f.u., a $\mathrm{Mg}$ content from $0.58-0.76$ a.p.f.u. and an $\mathrm{Fe}$ content from $1.70-1.86$ a.p.f.u.

Orthopyroxene. OpxI (stage 1 in basic granulite) and OpxII (stage 2 in granulite at the contact with migmatitic gneiss) are hypersthenic, with $\mathrm{X}_{\mathrm{Mg}}$ increasing from 0.47 (OpxI) to 0.61 (OpxII). $\mathrm{Al}$ in $\mathrm{Opx}$ ranges from 0.033 to 0.061 a.p.f.u.

Clinopyroxene. CpxI (stage 1 in basic granulites) and CpxII (stage 2 in granulite at the contact with migmatitic gneiss) are clino-hypersthenic, showing $\mathrm{X}_{\mathrm{Mg}}$ between 0.45 and 0.50. Al in $\mathrm{Cpx}$ ranges from 0.048 to 0.061 a.p.f.u.

Feldspars. PII in metapelite is characterized by a homogeneous $\mathrm{Ab}$ content of approximately 0.74 . The An content varies in PII, where it may increase up to 0.32 . In metabasite, PIII has a higher An content, which varies from 0.45 to 0.80 . Orthoclase occurs in association with PIII (KfsII) and within pegmatite veins (KfsIII).

Spinel. In migmatite (stage 2), spinel is part of a hercynite-spinel-ghanite solid solution, where $\mathrm{X}_{\mathrm{Spl}}$ varies from 0.25 to $0.39, \mathrm{X}_{\mathrm{Hc}}$ from 0.39 to 0.52 and $\mathrm{X}_{\text {Gah }}$ from 0.15 to 0.36 . 


\section{a) Biotite}
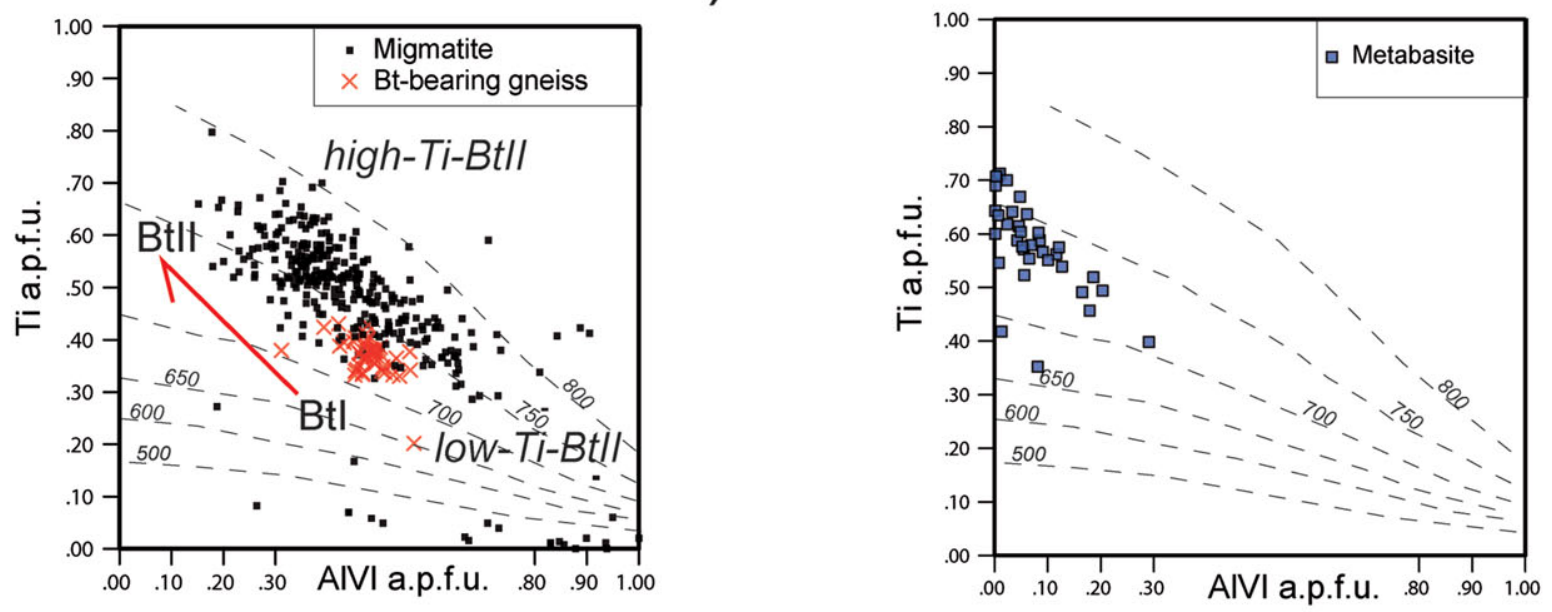

b) Amphibole

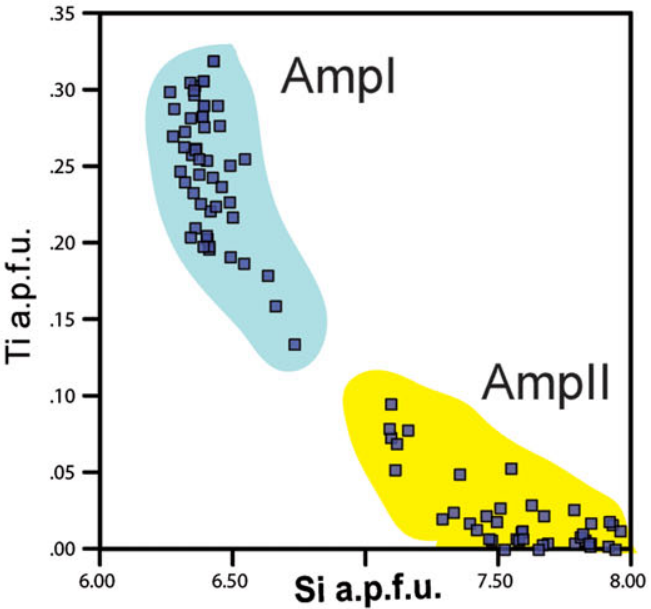

c) Garnet

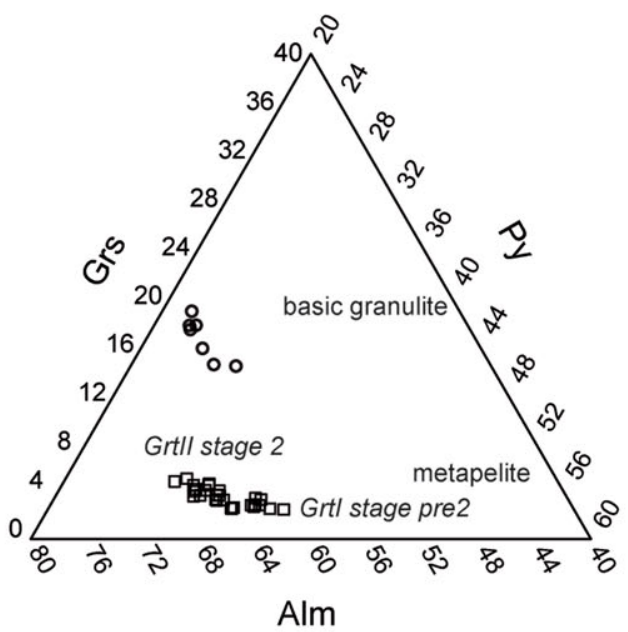

d) Pyroxene

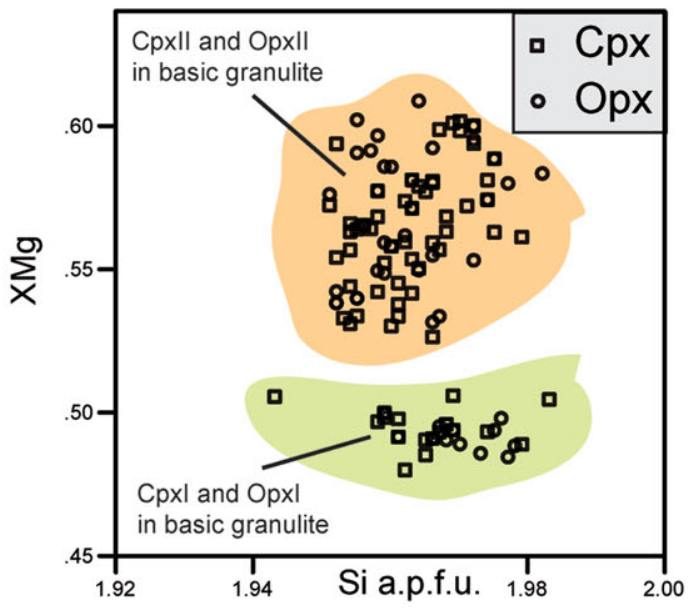

Figure 6. (Colour online) Graphic representation of the chemical composition of selected mineral phases: (a) biotite; $T^{\circ} \mathrm{C}$ isolines after Henry, Guidotti \& Thomson (2005); (b) amphibole; (c) garnet; (d) pyroxene. 


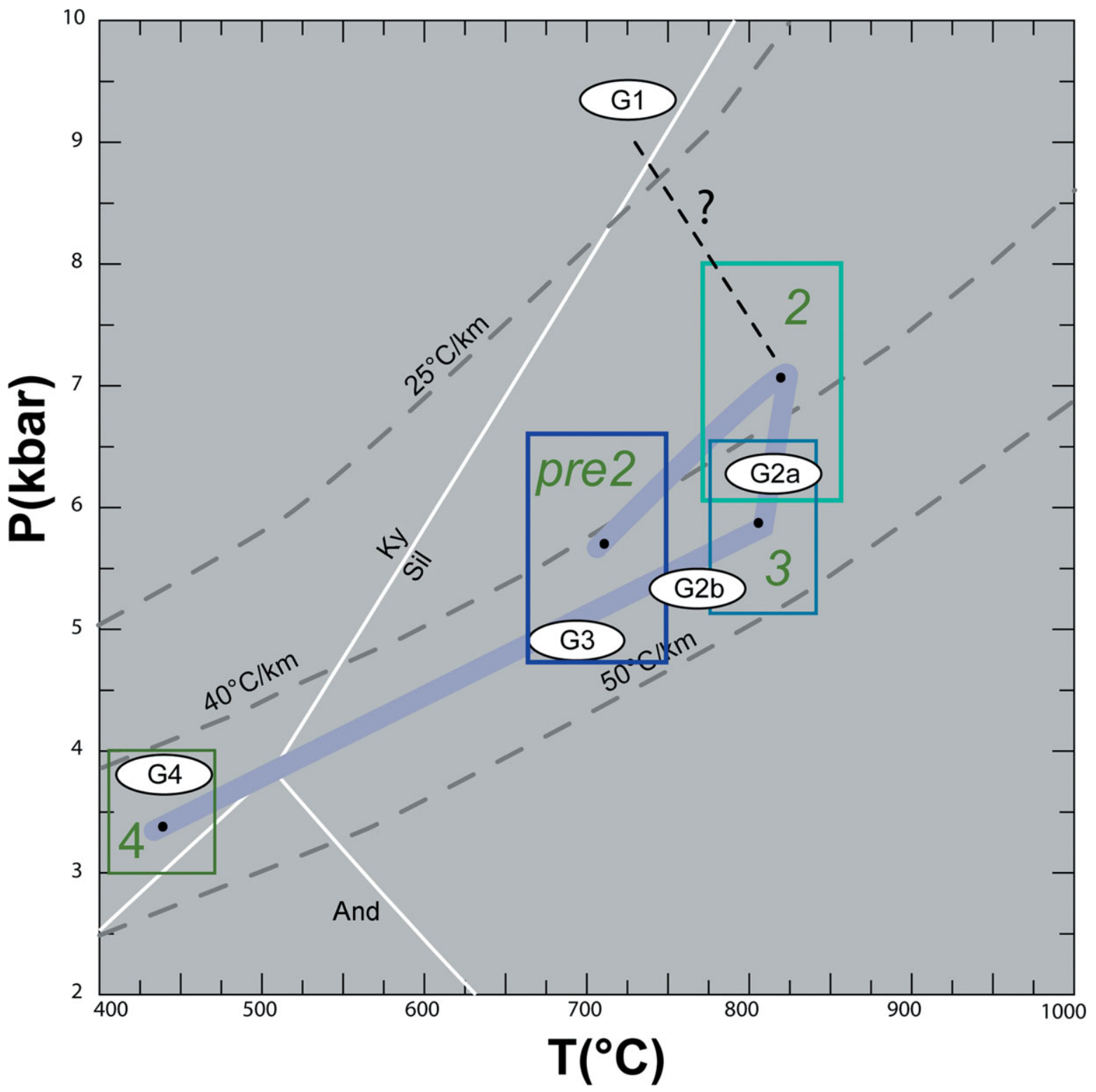

Figure 7. (Colour online) $P-T-t-\mathrm{d}$ paths reconstructed on the basis of meso- and microstructural relationships and $P-T$ estimates. G1, G2a, G2b, G3 and G4 stages from Gardien, Reusser \& Marquer (1994); boxes and chronology from this work. $25-40-50{ }^{\circ} \mathrm{C} \mathrm{km}^{-1}$ geothermal gradients are shown. Ky, And, Sil stability fields calculated using the thermodynamic database of Holland \& Powell (1998).

Table S1g in the online Supplementary Material available at http://journals.cambridge.org.geo also reports selected analyses of stage 4 chlorite and white mica. Chl compositions vary in the $\mathrm{Mg}, \mathrm{Al}$ and $\mathrm{Si}$ contents, whereas $\mathrm{Wm}$ compositions distinguish two generations that may be discriminated by the variations in the $\mathrm{Si}, \mathrm{Al}, \mathrm{Mg}$ and $\mathrm{Fe}$ contents.

\section{Estimates of pressure and temperature conditions}

Available petrogenetic grids and thermobarometry were used to estimate the physical conditions of metamorphic stages (Fig. 7), as reconstructed by mesoand microstructural analyses. Microstructural analysis allowed for the recognition of reactions that occurred during metamorphic evolution and their relative timing.
Mineral pairs and stable associations were used for thermobarometric estimates (Table 4). Pressure and temperature conditions and the reactions deduced by microstructures are compared with data available from petrogenetic grids. Temperatures were estimated using garnet-biotite $\mathrm{Fe}-\mathrm{Mg}$ exchange thermometry (Bhattacharya et al. 1992; Wu \& Cheng, 2006) and using the $\mathrm{Ti}$ content in biotite with the calibration of Henry, Guidotti \& Thomson (2005). The pressures were estimated using a garnet-aluminosilicate-silicaplagioclase (GASP) barometer for which the calibration of Holdaway (2001) was employed, and a using garnet-plagioclase-biotite-quartz (GPBQ) barometer with the calibration of Hodges \& Spear (1982). Average $P-T$ estimates were calculated using Thermocalc v. 3.33 (Holland \& Powell, 1998) in mode 2; the activities of the end-member minerals from chemical analyses 
Table 4. Thermobarometric estimates for the Valpelline rocks, with reference to the method used (see text for calibration references)

\begin{tabular}{|c|c|c|c|c|c|}
\hline stage & sample & $\mathrm{T}^{\circ} \mathrm{C} \pm \mathrm{sd}$ & $\mathrm{P}$ kbar ( $\pm \mathrm{sd})$ & rock & method \\
\hline Pre 2 & $\begin{array}{l}\text { P55 } \\
\text { P55 } \\
\text { P55 } \\
\text { P55 }\end{array}$ & $\begin{array}{l}741 \pm 25 \\
658 \pm 31 \\
710 \pm 15\end{array}$ & $\begin{array}{l}4.5-6.5 \\
4.7\end{array}$ & $\begin{array}{l}\text { gneiss } \\
\text { gneiss } \\
\text { gneiss } \\
\text { gneiss }\end{array}$ & $\begin{array}{l}\text { Ti in biotite } \\
\text { GPBQ } \\
\text { Grt-Bt_HL77 } \\
\text { GASP }\end{array}$ \\
\hline 2 & $\begin{array}{l}\text { P74_HTi } \\
\text { P28-3084 } \\
\text { P72B-P36 } \\
\text { P74-P55 } \\
\text { P74-P55 } \\
\text { P28 } \\
\text { P74-P66-P67-P74 } \\
\text { P72B-P36 }\end{array}$ & $\begin{array}{l}819 \pm 50 \\
781 \pm 2 \\
797 \pm 6 \\
873 \pm 16 \\
844 \pm 21 \\
813 \pm 104\end{array}$ & $\begin{array}{l}8 \\
5-8 \\
7.6 \pm 1.7\end{array}$ & $\begin{array}{l}\text { migmatite } \\
\text { migmatite } \\
\text { granulite } \\
\text { migmatite+gneiss } \\
\text { migmatite+gneiss } \\
\text { migmatite } \\
\text { migmatite } \\
\text { granulite }\end{array}$ & $\begin{array}{l}\text { Ti in biotite } \\
\text { Ti in biotite } \\
\text { Ti in biotite } \\
\text { Grt-Bt } \\
\text { GASP } \\
\text { Grt-Bt } \\
\text { GPBQ } \\
\text { avPT }\end{array}$ \\
\hline 3 & P16-P36-P72B-P27-P3083 & $\begin{array}{l}855 \pm 12 \\
829 \pm 10 \\
824 \pm 50 \\
780 \pm 22\end{array}$ & $\begin{array}{l}5-6.5 \\
5-6.5\end{array}$ & $\begin{array}{l}\text { amphibolite } \\
\text { amphibolite } \\
\text { amphibolite } \\
\text { amphibolite }\end{array}$ & $\begin{array}{l}\text { Al-tot Amp } \\
\text { Pl-Amp } \\
\text { Ti-Amp } \\
\text { Ti-Bt }\end{array}$ \\
\hline 4 & $\begin{array}{l}\text { P55-P3085-P25 } \\
\text { P42-P3082-P3083 }\end{array}$ & $\begin{array}{l}339 \pm 16 \\
455 \pm 38\end{array}$ & & $\begin{array}{l}\text { migmatite } \\
\text { amphibolite }\end{array}$ & $\begin{array}{l}\text { AlIV-Chl } \\
\text { AlIV-Chl }\end{array}$ \\
\hline
\end{tabular}

avPT - Thermocalc v. 3.33 mode 2 calculations using activities from microprobe analysis as input.

were calculated using AX software (Holland, 2000) and used as input.

Stage pre2 is preserved in different lithologies (Btbearing gneisses, Opx-bearing granulites, amphibolites and Ol-bearing marbles), and frequently, this stage is associated with the development of the $S_{\text {prez }}$ foliation. Thermobarometric estimates on mineral pairs and stable associations for stage pre2 in Bt-bearing gneiss are shown in Table 4; temperatures are between $703 \pm$ $42{ }^{\circ} \mathrm{C}$, and pressures are in the range of 4.5 to $6.5 \mathrm{kbar}$. Similar $P-T$ intervals are shown by $P-T$ pseudosections reconstructed for comparable bulk compositions in the model system $\mathrm{Na}_{2} \mathrm{O}-\mathrm{CaO}-\mathrm{K}_{2} \mathrm{O}-\mathrm{FeO}-\mathrm{MgO}-\mathrm{Al}_{2} \mathrm{O}_{3}-$ $\mathrm{SiO}_{2}-\mathrm{H}_{2} \mathrm{O}$ (NCKFMASH) (e.g. White, Powell \& Holland, 2001) for the Bt-bearing assemblages in the absence of melt.

During stage 2, a pervasive migmatization affects metapelites, and a centimetre- to millimetre-thick $S_{2}$ foliation develops, which is marked by the alternation of leucosome and melanosome. Some microstructures recognized in migmatites (e.g. growth twins and SillII associated with GrtII) suggest crystallization and growth processes from a melt, and these microstructures may be a result of melt-producing continuous reactions involving $\mathrm{Bt}$ as a reactant (White, Powell \& Holland, 2001; White \& Powell, 2002), indicating $T \geq 800^{\circ} \mathrm{C}$ and $P>6$ kbar. The rare appearances of garnet + cordierite + orthopyroxene by biotitemelting reactions have been recently investigated using a $P-T$ pseudosections approach (Johnson, White \& Powell, 2008) and in natural rocks (Bhandari et al. 2011). Bhandari et al. (2011) also observed that garnet grew to the exclusion of cordierite and orthopyroxene in a relatively ferroan bulk-rock composition, whereas garnet and cordierite appeared in more magnesian and aluminous compositional domains. The biotite-melting reactions suggested by the authors for the NCKFMASH system are $B t+P l+Q z=G r t+K f s+$ melt (for garnet alone), $B t+S i l+P l+Q z=G r t+C r d+K f s+$ melt and $\mathrm{Bt}+\mathrm{Pl}+\mathrm{Qz}=\mathrm{Grt}+\mathrm{Crd}+\mathrm{Kfs}+$ melt (for garnet + cordierite), thereby producing mineral associations similar to those that were stable during this stage and indicating $T>770^{\circ} \mathrm{C}$ at $P>6 \mathrm{kbar}$ (Johnson, White \& Powell, 2008). Gardien, Reusser \& Marquer (1994) estimated $P>5 \mathrm{kbar}$ at $T>750^{\circ} \mathrm{C}$ for this stage. Thermobarometric estimates on mineral pairs and stable associations of stage 2 in migmatites result in $T=814 \pm 40^{\circ} \mathrm{C}$ and a $P$ interval of $6-8 \mathrm{kbar}$ (Table 4).

Stages $3 \mathrm{a}$ and $3 \mathrm{~b}$ comprise two superimposed deformational phases that rework the pre-existing structures. Both deformational phases are marked by the same metamorphic minerals (BtII + SilII + GrtII layers and QzII + PIII + KfsII lithons). Gardien, Reusser \& Marquer (1994) estimated a pressure of 4-6 kbar and temperature of $750-800{ }^{\circ} \mathrm{C}$ for these stages, characterized by the assemblage $\mathrm{Bt}+\mathrm{Sil}+$ $\mathrm{Pl}+\mathrm{Qz} \pm \mathrm{Grt} \pm \mathrm{Kfs}$ in metapelite. On the basis of the absence of cordierite in migmatite and using the experimental curve Phl + Sil + Qz $=$ Mg-Crd (Spear \& Cheney, 1989), Gardien, Reusser \& Marquer (1994) constrained the lower pressure for the same stages at 5.5 kbar. This curve cross-cuts at $6 \mathrm{kbar}$ the experimental curve between medium pressure and low pressure granulites calibrated by Green \& Ringwood (1967). Thermobarometric estimates on mineral pairs and stable associations of stages $3 \mathrm{a}$ and $3 \mathrm{~b}$ in amphibolite indicate temperatures of $822 \pm 31^{\circ} \mathrm{C}$ and pressures of 5-6.5 kbar (Table 4). Stage 3 is also characterized by the crystallization of the magmatic assemblage Grt + $\mathrm{Bt}+\mathrm{Kfs}+\mathrm{Qz}$ in leucosomes (i.e. pegmatites). This assemblage is related to the melt-producing reactions involving $\mathrm{Bt}+\mathrm{Sil}+\mathrm{Qz}+\mathrm{Pl}$ as reactants at $T>$ $800^{\circ} \mathrm{C}$ and $P>6 \mathrm{kbar}$ (White, Powell \& Holland, 2001; Johnson, White \& Powell, 2008). This $P-T$ estimate agrees with the mesoscopic observations that 


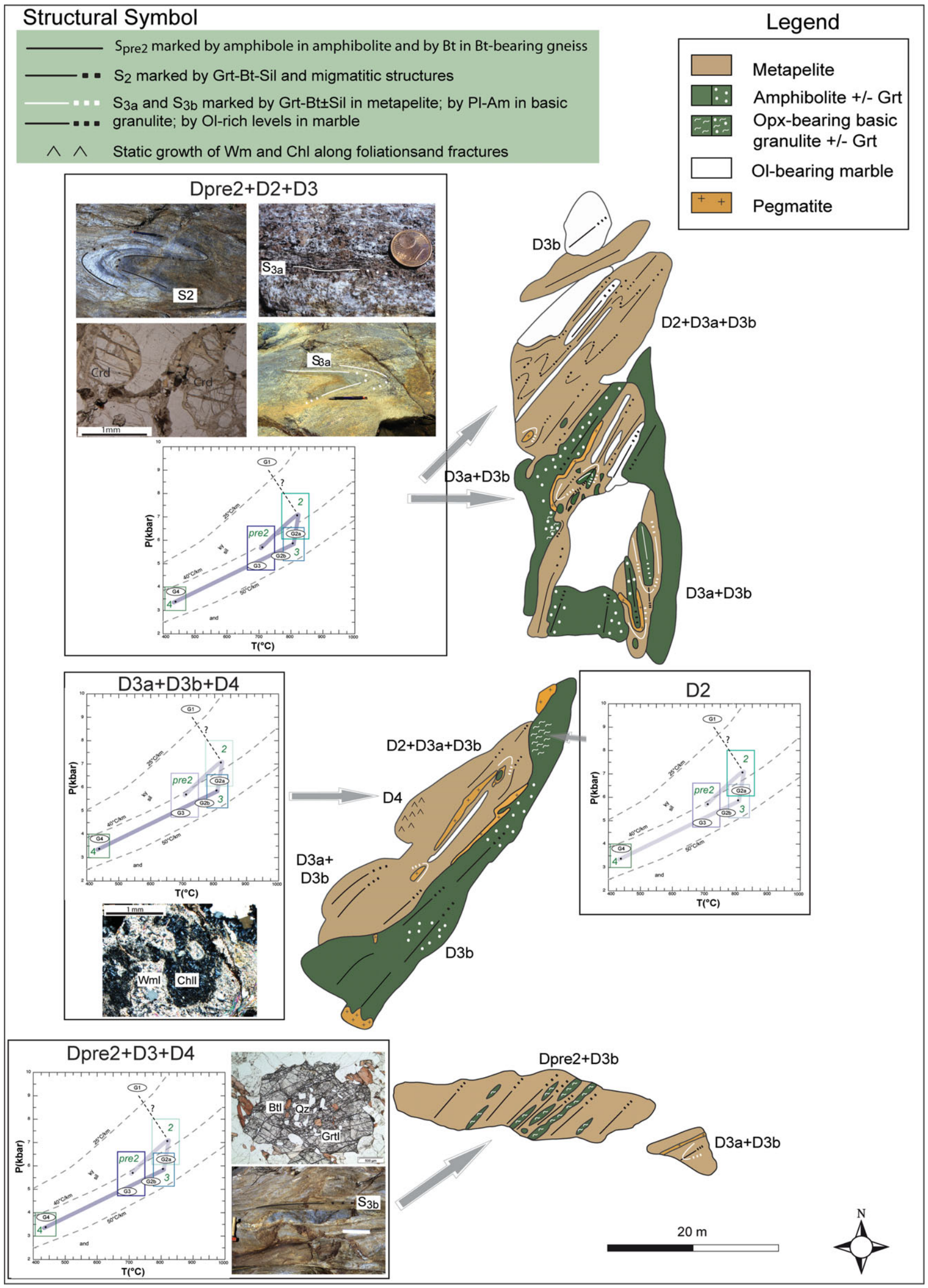

Figure 8. (Colour online) Structural and metamorphic map of the study area, showing metre-scale relationship between lithologies, superimposed structures and relative fabric-supporting minerals related to the recorded metamorphic imprints. On the map, the dots along the foliations trace the relative chronology of superimposed foliations. Mineral assemblages related to successive fabrics in each rock type are represented by differently coloured trajectories and by different symbols associated with the trajectories (Spalla et al. 
suggest the contemporaneous development of Grtbearing leucosomes and of the $\mathrm{S}_{2}$ and $\mathrm{S}_{3}$ foliations.

During stage 4, WmI and EpI replace $\mathrm{Pl}$, following the reaction $\mathrm{Pl}+\mathrm{H}_{2} \mathrm{O}=\mathrm{EpI}+\mathrm{WmI}+\mathrm{Qz}$ (Holland $\&$ Powell, 1998). Gardien, Reusser \& Marquer (1994) described a similar pre-Alpine metamorphic imprint occurring under greenschist facies conditions $(T<$ $500{ }^{\circ} \mathrm{C}$ and $\mathrm{P} \approx 3-4 \mathrm{kbar}$ ). $\mathrm{Kfs}+\mathrm{Sil}+\mathrm{H}_{2} \mathrm{O}=\mathrm{Wm}+$ $Q z+L$ and $\mathrm{Bt}+\mathrm{Kfs}+\mathrm{Sil}+\mathrm{H}_{2} \mathrm{O}=\mathrm{Wm}+\mathrm{Qz}$ reactions may also indicate the replacement of Sil, Bt and $\mathrm{Kfs}$ by $\mathrm{WmI}$ and Qz. During the same stage, $\mathrm{Bt}$ and Grt are replaced by ChlI, probably through the reaction $\mathrm{Grt}+\mathrm{Bt}+\mathrm{Sil}+\mathrm{H}_{2} \mathrm{O}=\mathrm{Chl}+\mathrm{Wm}+\mathrm{Qz}$ (Spear \& Cheney, 1989). The AlIV content in the Chl thermometer (Chatelineau, 1988) infers $T=339 \pm$ $16^{\circ} \mathrm{C}$ in Bt-bearing gneiss and migmatite and $T=$ $455 \pm 38^{\circ} \mathrm{C}$ in amphibolite.

\section{Discussion and interpretation}

\section{7.a. Tectonometamorphic evolution}

The Valpelline unit is characterized by a polyphase evolution from pre-Permian to Alpine age and under granulite to greenschist facies conditions. In the studied area $(300 \times 50 \mathrm{~m})$, the deformational and metamorphic imprints are heterogeneously distributed in space, thereby producing a chronological and spatially heterogeneous network of structures and metamorphic associations (Fig. 8). In the studied rocks, the preAlpine history is characterized by four evolutionary stages.

Stage pre2 comprises a complex structural and metamorphic evolution prior to stage 2 . In this stage, we group several phases of deformation and metamorphism recorded in different lithologies (Ol-bearing marbles, Bt-bearing gneiss, amphibolites, and boudins of Opx-bearing basic granulites within migmatites) and characterized by contrasting $P-T$ conditions. A weak foliation $\left(\mathrm{S}_{\text {pre2 }}\right)$ is locally recognizable at the meso- or micro-scale.

Thermobarometric estimates from Bt-bearing gneiss give estimates of $T=700 \pm 50^{\circ} \mathrm{C}$ and $P=5.7 \pm 1$ kbar (Fig. 7).

In a nearby area of the Valpelline, Gardien, Reusser \& Marquer (1994) recognized earlier stages of a high pressure granulite facies evolution in Bt-bearing gneiss, as indicated by kyanite-rutile-alkali feldspar relics in metapelites $\left(700^{\circ} \mathrm{C}\right.$ at $\left.9.3 \mathrm{kbar}\right)$.

Stage 2 is characterized by the growth of Grt in basic granulites, thereby producing the stable assemblage Opx $+\mathrm{Cpx}+\mathrm{Pl}+\mathrm{Grt}$, whereas in metapelites, migmatitic structures largely develop that are associated with diffuse melt-producing reactions. The temperature $\left(810 \pm 40^{\circ} \mathrm{C}\right)$ and pressure $(7 \pm 1$ kbar) attained during stage 2 (Fig. 7) indicates a > $35-40{ }^{\circ} \mathrm{C} \mathrm{km}^{-1}$ geothermal gradient.

Stages $3 \mathrm{a}$ and $3 \mathrm{~b}$ correspond to a progressive deformation $\left(\mathrm{S}_{3 \mathrm{a}}\right.$ and $\mathrm{S}_{3 \mathrm{~b}}$ foliations and isoclinal folds) under amphibolite to granulite metamorphic conditions that is well preserved in metabasites and metapelites, where these stages are associated with the production of Grt-bearing melts (metre-thick leucosome bodies and veins). The temperature $\left(800 \pm 30^{\circ} \mathrm{C}\right)$ and pressure ( $6 \pm 0.7$ kbar) attained during stage 3 (Fig. 7) still indicates a high geothermal gradient $>40^{\circ} \mathrm{C} \mathrm{km}^{-1}$.

The last recorded stage of the evolution is stage 4 . Stage 4 is not pervasive, and it is associated with the static growth of $\mathrm{Chl}$ and $\mathrm{Wm}$ on Bt. This stage occurs under greenschist facies conditions $\left(T=430 \pm 30^{\circ} \mathrm{C}\right.$ at $P=3.5 \pm 0.5 \mathrm{kbar}$ ). During this stage, faults and cataclasites also affect all lithologies, as shown for the surrounding rocks of the Arolla unit (Roda \& Zucali, 2008).

\section{7.b. Age constraints and geodynamic implications}

Several considerations may be proposed for the preAlpine evolution described above.

Stage pre 2 reflects a Variscan high thermal gradient, as inferred from abundant basic granulites and Btbearing gneiss. Gardien, Reusser \& Marquer (1994) recognized earlier stages of a high pressure granulite facies evolution that may have recorded the crustal thickening associated with the Variscan collision thickening. The earlier stages (Gardien, Reusser \& Marquer, 1994) and those found in the present study may indicate that separate tectonic subunits were decoupled during the Variscan. The later juxtaposition of these stages would imply either a collisional extrusion of the lower subunit at the end of the Variscan or a Permian extension during lithospheric thinning and continental rifting. Further studies (i.e. a geochronological study of the kyanite-bearing metapelites found by Gardien, Reusser \& Marquer, 1994) are needed to encompass this stage and might help to distinguish between the two hypotheses proposed.

Stages 2 and 3 are characterized by melt-producing reactions and migmatites and by the emplacement of a large amount of melt along veins and dykes. This evolution and the related thermal gradient may be ascribed to the late-Variscan-Permian high thermal event, which is widely reported in the Variscan history of the European continental crust and generally associated with the post-collisional thinning to PermoTriassic rifting (Weber, 1984; Lardeaux \& Spalla, 1991; Schuster \& Stüwe, 1991; Bonin et al. 1993; Müntener \& Hermann, 2001). Generally, the intrusion of large igneous bodies across the pre-Alpine continental crust is also associated with this evolution (Bonin et al. 1993;

2000). Also shown are heterogeneous $P-T-t-\mathrm{d}$ memories, registered in adjacent rock domains. The figure shows distribution of domains where structural and metamorphic imprints are better recorded with respect to degree of fabric development. Pencil for scale is $13 \mathrm{~cm}$ long; coin is $1 \mathrm{~cm}$ in diameter; ruler is $20 \mathrm{~cm}$ long; and hammer is $40 \mathrm{~cm}$ long. 
Marotta \& Spalla, 2007; Marotta, Spalla \& Gosso, 2009 and references therein). In the case of the Valpelline unit, Permian intrusions occur within the adjacent Arolla unit, which is composed of granitic to gabbroic igneous intrusions of Permian age (i.e. Collon and Cervino gabbros: $250 \pm 5 \mathrm{Ma}, \mathrm{K}-\mathrm{Ar}, \mathrm{Rb}-\mathrm{Sr}$ (Dal Piaz, De Vecchi \& Hunziker, 1977); $284 \pm 0.6 \mathrm{Ma}$, U-Pb (Monjoie et al. 2005); Arolla granites: $289 \mathrm{Ma}$ (Bussy et al. 1998)). Within the Arolla intrusives, several roof pendants and xenolite fragments of various sizes (a few to hundreds of metres in length) were found. These intrusives are also represented by amphibolites, biotiteand garnet-bearing gneisses and acid granulites (Diehl, Masson \& Stutz, 1952; Roda \& Zucali, 2008). The lithological similarities between the Arolla xenolites and Valpelline lithotypes (acid granulites, gneisses and amphibolites) along with the high temperature imprint recorded in the described lithotypes suggest that the Valpelline unit is older than the Permian Arolla intrusions (i.e. 250-290 Ma).

Permian magmatism and HT-LP metamorphism affecting the Alpine continental crust have been related to the late orogenic collapse of the Variscan belt (Malavielle et al. 1990; Ledru et al. 2001) or as a consequence of lithospheric thinning leading to continental rifting, as proposed for the Austroalpine and Southalpine domains (Diehl, Masson \& Stutz, 1952; Lardeaux \& Spalla, 1991; Diella, Spalla \& Tunesi, 1992; Müntener \& Hermann, 2001; Schuster \& Stüwe, 2008).

The second hypothesis appears more suitable because at the Carboniferous/Permian boundary, the Palaeozoic plate convergence is replaced by a transtensional to extensional tectonic regime, which promoted the break-up of Pangaea (Marotta \& Spalla, 2007; Schuster \& Stüwe, 2008). In the Austroalpine and Southalpine domains, the Permian radiometric ages have been interpreted as representing metamorphic and igneous markers of earlier stages of Mesozoic rifting (Lardeaux \& Spalla, 1991; Quick et al. 1992; Dal Piaz, 1993; Thoni \& Miller, 2000), whereas the Triassic ages have been interpreted as either minimal ages of thermal pulses during extension-related decompression (Vavra, Schmid \& Gebauer, 1999) or resulting from a later regional thermal event (Lu et al. 1997). In the Southalpine domain the stratigraphic sequences also document late Carboniferous to Carnian transtension followed by Carnian to Cretaceous rifting to drifting (Gaetani et al. 1998; Muttoni et al. 2003).

The high thermal gradient and the extensive production and segregation of melt recorded in the metapelites of the Valpelline unit seem to support the high thermal regime associated with the syn-rifting crustal thinning. Dating of accessory phases (allanite, zircon and titanite) in metasediments amalgamated with the gneisses of the Arolla Series, points to Permian metamorphism between $\sim 300$ and $265 \mathrm{Ma}$ (Manzotti et al. 2012). Absolute age data for the Valpelline unit are too sparse and difficult to interpret (Hunziker,
1974) for a confident constraining of the tectonic evolution. The only age constraints are generally inferred from lithological similarities and structural relationships with adjacent units (e.g. Arolla) or on the basis of lithological-metamorphic comparisons with other units of the Alpine-European chain, which are characterized by similar lithostratigraphic, structural or metamorphic imprints (Spalla \& Marotta, 2007; Schuster \& Stüwe, 2008; Marotta, Spalla \& Gosso, 2009). Preliminary U-Pb dating on zircon from a pegmatite in the Valpelline unit indicates the Permian period $(\sim 270 \mathrm{Ma})$ for the high temperature metamorphism (Zucali et al. 2011). Reliable age data would be crucial to relate the local thermal and mechanical history to the geodynamics at the lithosphere scale during Variscan to Permian times.

The well-preserved structural and metamorphic history of this small portion of the Valpelline basement makes possible a first attempt at an interpretation of the pre-Alpine geodynamics of this unit. An extension of this approach to adjacent portions of the Valpelline unit will help to shed light on the transition between the late orogenic collapse of the Variscan chain and the lithospheric thinning that promoted the opening of the Tethys Ocean.

Acknowledgements. M. Engi and M. I. Spalla are thanked for discussion and reading of early versions of the manuscript; Andrea Risplendente at Microprobe Lab and Agostino Rizzi at SEM (CNR-IDPA) Lab at Dipartimento di Scienze della Terra 'A. Desio' - Università degli Studi di Milano are also thanked for technical support. Marco Malusà is thanked for a constructive review.

\section{References}

ARgand, E. 1906. Sur la carte tectonique du Massif de la Dent Blanche. Comptes Rendus de l'Académie des Sciences Paris 142, 527-29.

BAllÈVRe, M. \& KienAST, J. R. 1987. Decouverte et signification de parageneses a grenat-amphibole bleu dans la couverture mesozoique de la nappe de la Dent-Blanche (Alpes Occidentales). Comptes Rendus de l'Académie des Sciences Paris 305, 43-6.

Bhandari, A., PANT, N. C., BHOWMIK, S. K. \& GoSWAMI, S. 2011. $\sim 1.6 \mathrm{Ga}$ ultrahigh-temperature granulite metamorphism in the Central Indian Tectonic Zone: insights from metamorphic reaction history, geothermobarometry and monazite chemical ages. Geological Journal 46, 198-216.

Bhattacharya, A., Mohanty, L., Maji, A., Sen, S. K. \& RAITH, M. 1992. Non-ideal mixing in the phlogopiteannite binary: constraints from experimental data on $\mathrm{Mg}$-Fe partitioning and a reformulation of the biotitegarnet geothermometer. Contributions to Mineralogy and Petrology 111, 87-93.

BOHLEN, S. R. 1987. Pressure-temperature-time paths and a tectonic model for the evolution of granulites. Journal of Geology 95, 617-32.

Bonin, B., Braendlein, P., Bussy, F., Desmons, J. \& EgGenberger, U. 1993. Late Variscan magmatic evolution of the Alpine basement. In Pre-Mesozoic Geology in the Alps (eds J. F. von Raumer \& F. Neubauer), pp. 171-201. Berlin \& Heidlberg: Springer-Verlag. 
Bussy, F., Venturini, G., Hunziker, J. C. \& MARtinotTi, G. 1998. U-Pb ages of magmatic rocks of the Western Austroalpine Dent-Blanche-Sesia Unit. Schweizerische Mineralogische und Petrographische Mitteilungen 78, 163-68.

Caby, R., Kienast, J. R. \& SAliot, P. 1978. Structure, metamorphism and model of tectonic evolution of the Western Alps. Revue de Geographie Physique et de Geologie Dynamique 20, 307-22.

Canepa, A., Castelletto, M., Cesare, B., Martin, S. \& ZAGGIA, L. 1990. The Austroalpine Mont Mary nappe (Italian Western Alps). Memorie di Scienze Geologiche 42, 1-17.

Chatelineau, M. 1988. Cation site occupancy in chlorites and illites as a function of temperature. Clay Minerals 23, 471-85.

DAl PIAZ, G. V. 1993. Evolution of Austrolapine and Upper Penninic basement in the northwestern Alps from Variscan convergence to post-Variscan extension. In Pre-Mesozoic Geology in the Alps (eds J. F. von Raumer \& F. Neubauer), pp. 325-42. Berlin \& Heidlberg: Spring-Verlag.

Dal Piaz, G. V., De Vecchi, G. \& Hunziker, J. C. 1977. The Austroalpine layered gabbros of the Matterhorn and Mt. Collon-Dents de Bertol. Schweizerische Mineralogische und Petrographische Mitteilungen 57, 59-88.

DeER, W. A., HowIe, R. A. \& Zussman, J. 1996. An Introduction to the Rock-Forming Minerals. New York: Prentice Hall.

DE LeO, S., BiInO, G. \& Compagnoni, R. 1987. Riequilibrazioni metamorfiche alpine nella serie di Valpelline e di Arolla a Nord di Bionaz (Valpelline-Aosta). Rendiconti della Società Italiana di Mineralogia e Petrologia 42, 181-82.

De GiUsti, F., Dal Piaz, G. V., Massironi, M. \& Schiavo, A. 2003. Carta geotettonica della Valle d'Aosta. Memorie di Scienze Geologiche 55 (2003/2004), 12949.

Diehl, E. A., MAsson, R. \& StUTZ, A. H. 1952. Contributo alla conoscenza del ricoprimento della Dent Blanche. Memorie degli Istituti di Geologia e Mineralogia dell'Università di Padova 17, 1-52.

Diella, V., Spalla, M. I. \& Tunesi, A. 1992. Contrasting thermomechanical evolutions in the southalpine metamorphic basement of the Orobic Alps (Central Alps, Italy). Journal of Metamorphic Geology 10, 203-19.

ELLIS, D. J. 1987. Origin and evolution of granulites in normal thickened crusts. Geology 15, 167-70.

GaEtani, M., Gnacollini, M., Jadoul, F. \& GarZanti, E. 1998. Multiorder sequence stratigraphy in the Triassic system of the western Southern Alps. In Mesozoic and Cenozoic Sequence Stratigraphy of European Basins (eds P. C. De Graciansky, J. Hardenbol, T. Jacquin \& P. R. Vail), pp. 701-17. Society for Sedimentary Geology (SEPM) Special Publication 60.

Galli, A., Le Bayon, B., Schmidt, M. W., Burg, J. P., Reusser, E., Sergeev, S. A. \& Larionov, A. 2012. $\mathrm{U}-\mathrm{Pb}$ zircon dating of the Gruf Complex: disclosing the late Variscan granulitic lower crust of Europe stranded in the Central Alps. Contributions to Mineralogy and Petrology 163, 353-78.

GARDIEN, V. 1994. Occurrence of kyanite in the gneisses from the Valpelline Series (Dent-Blanche Nappe, Western Alps). Comptes Rendus de l'Academie des Sciences Paris, Serie 2 319, 899-905.

Gardien, V., Reusser, E. \& Marquer, D. 1994. PreAlpine metamorphic evolution of the gneisses from the Valpelline Series (Western Alps, Italy). Schweizerische
Mineralogische und Petrographische Mitteilungen 74, 489-502.

GREen, D. H. \& Ringwood, A. E. 1967. An experimental investigation of the gabbro to eclogite transformation and its petrological applications. Geochimica et Cosmochimica Acta 31, 767-833.

HARLEY, S. L. 2008. Refining the P-T records of UHT crustal metamorphism. Journal of Metamorphic Geology 26, $125-54$.

Henry, B., Guidotti, C. V. \& Thomson, J. A. 2005. The Ti-saturation surface for low-to-medium pressure metapelitic biotite: implications for geothermometry and Ti-substitution mechanisms. American Mineralogist 90, 316-28.

Hodges, K. V. \& Spear, F. S. 1982. Geothermometry, geobarometry and the $\mathrm{Al}_{2} \mathrm{SiO}_{5}$ triple point at $\mathrm{Mt}$ Moosilauke, New Hampshire. American Mineralogist 67, 1118-34.

HOLDAWAY, M. J. 2001. Recalibration of the GASP geobarometer in light of recent garnet and plagioclase activity models and versions of the garnet-biotite geothermometer. American Mineralogist 86, 1117 29.

Holland, T. 2000. AX: a program to calculate activities of mineral end members from chemical analyses which uses the activity models outlined in Holland \& Powell (1998). http://www.esc.cam.ac.uk/research/ research-groups/holland/ax

Holland, J. B. \& POWELL, R. 1998. An internally consistent thermodynamic data set for phases of petrologic interest. Journal of Metamorphic Geology 16, 309-43.

HUNZIKER, J. C. 1974. Rb-Sr and K-Ar determination and the Alpine tectonic history of the Western Alps. Memorie degli Istituti di Geologia e Mineralogia dell'Università di Padova 31, 1-54.

Johnson, T. E., White, R. W. \& Powell, R. 2008. Partial melting of metagreywacke: a calculated mineral equilibria study. Journal of Metamorphic Geology 26, 837-53.

KIENAST, J. R. \& NiCOT, E. 1971. Presence of a disthene paragenesis and chloritoid probably Alpine in sillimanite gneiss, garnet and cordierite of Valpelline (Val Daoste, Italy). Comptes Rendus Hebdomadaires des Seances de l'Academie des Sciences Serie D 272, 1836-40.

Kriegsman, L. M. \& Alvarez-Valero, A. M. 2010. Meltproducing versus melt-consuming reactions in pelitic xenoliths and migmatites. Lithos 116, 310-20.

LardeauX, J. M. \& Spalla, M. I. 1991. From granulites to eclogites in the Sesia Zone (Italian Western Alps) a record of the opening and closure of the Piedmont Ocean. Journal of Metamorphic Geology 9, 35-59.

Ledru, P., Courrioux, G., Dallain, C., Lardeaux, J. M., Montel, J. M., VAnderhaeghe, O. \& Vitel, G. 2001. The Velay dome (French Massif Central): melt generation and granite emplacement during orogenic evolution. Tectonophysics 342, 207-37.

Lu, M. H., Hofmann, A. W., Mazzucchelli, M. \& RIVALENTI, G. 1997. The mafic-ultramafic complex near Finero (Ivrea-Verbano Zone). 2. Geochronology and isotope geochemistry. Chemical Geology 140, 22335 .

Malavielle, J., Guihot, P., Costa, S., LardeauX, J. M. \& GARDIEN, V. 1990. Collapse of the thickened Variscan crust in the French Massif Central: Mont Pilat extensional shear zone and St. Etienne Late Carboniferous basin. Tectonophysics 177, 139-49.

Malusà, M., Faccenna, C., Garzanti, E. \& Polino, R. 2011. Divergence in subduction zones and exhumation 
of high pressure rocks (Eocene Western Alps). Earth and Planetary Science Letters 310, 21-32.

MANZOTTI, P. 2011. Petro-structural map of the Dent Blanche tectonic system between Valpelline and Valtournenche valleys, Western Italian Alps. Journal of Maps v2011, 340-52.

Manzotti, P., Rubatto, D., Darling, J., Zucali, M., Cenki-ToK, B. \& Engi, M. 2012. From Permo-Triassic lithospheric thinning to Jurassic rifting at the Adriatic margin: petrological and geochronological record in Valtournenche (Western Italian Alps). Lithos 146-147, 276-92.

Marschall, H. R., Kalt, A. \& Hanel, M. 2003. P-T evolution of a Variscan lower-crustal segment: a study of granulites from the Schwarzwald, Germany. Journal of Petrology 44, 227-53.

Marotta, A. M. \& Spalla, M. I. 2007. Permian-Triassic high thermal regime in the Alps: result of late Variscan collapse or continental rifting? Validation by numerical modeling. Tectonics 26, TC4016, doi: 10.1029/2006TC002047, 27 pp.

Marotta, A. M., Spalla, M. I. \& Gosso, G. 2009. Upper and lower crustal evolution during lithospheric extension: numerical modelling and natural footprints from the European Alps. Extending a Continent: Architecture, Rheology and Heat Budget (eds U. Ring \& B. Wernicke), pp. 33-72. Geological Society of London, Special Publication no. 321.

Monjoie, P., Bussy, F., Lapierre, H. \& Pfeifer, H. R. 2005. Modeling of in-situ crystallization processes in the Permian mafic layered intrusion of Mont Collon (Dent Blanche nappe, western Alps). Lithos 83, 317-46.

Müntener, O. \& HERMANN, J. 2001. The role of lower crust and continental upper mantle during formation of non-volcanic passive margins: evidence from the Alps. In Non-Volcanic Rifting of Continental Margins: A Comparison of Evidence from Land and Sea (eds. R. C. L. Wilson, R. B. Whitmarsh, B. Taylor \& N. Froitzheim), pp. 267-88. Geological Society of London, Special Publication no. 187.

Muttoni, G., Kent, D. V., Garzanti, E., Brack, P., Abrahamsen, N. \& Gaetani, M. 2003. Early Permian Pangea 'B' to Late Permian Pangea 'A'. Earth and Planetary Science Letters 215, 379-94.

PASSChIER, C. W. \& Trouw, R. A. J. 2005. Microtectonics. Berlin: Springer, 366 pp.

Pennacchioni, G. \& Guermani, A. 1993. The mylonites of the Austroalpine Dent Blanche nappe along the northwestern side of the Valpelline Valley (Italian Western Alps). Memorie di Scienze Geologiche 45, 3755.

Pin, C. \& Vielzeuf, D. 1983. Granulites and related rocks in Variscan median Europe: a dualistic interpretation. Tectonophysics 93, 47-74.

PIN, C. \& VielzeUf, D. 1988. Les granulites de hautepression d'Europe moyenne témoins d'une subduction éo-hercynienne. Implications sur l'origine des goupes leptyno-amphibolitiques. Bulletin de la Societe Geologique de France 1, 3-20.

Quick, J. E., Sinigoi, S., Negrini, L., Demarchi, G. \& MAYER, A. 1992. Synmagmatic deformation in the underplated igneous complex of the Ivrea-Verbano Zone. Geology 20, 613-16.

RoDA, M. \& ZUCALI, M. 2008. Meso and microstructural evolution of the Mont Morion metaintrusives complex (Dent Blanche nappe, Austroalpine domain, Valpelline, Western Italian Alps). Italian Journal of Geosciences 127, 105-23.
RoDA, M. \& ZUCALI, M. 2011. Tectono-metamorphic map of the Mont Morion Permian metaintrusives (Mont Morion - Mont Collon - Matterhorn Complex, Dent Blanche Unit), Valpelline - Western Italian Alps. Journal of Maps v2011, 519-35.

SAWYER, E. W. 2008. Working with Migmatites. Short Course Series: Mineralogical Association of Canada, vol. 38. Quebec: Mineralogical Association of Canada, $158 \mathrm{pp}$.

SCHEURS, J. 1985. Prograde metamorphism of metapelites, garnet-biotite thermometry and prograde change of biotite chemistry in high grade rocks of West Uusimaa, southwest Finland. Lithos 18, 69-80.

Schuster, R. \& StÜWE, K. 2008. Permian metamorphic event in the Alps. Geology 36, 603-6.

Searle, M. P., Cottle, J. M., Streule, M. J. \& Waters, D. J. 2010. Crustal melt granites and migmatites along the Himalaya: melt source, segregation, transport and granite emplacement mechanisms. Earth and Environmental Science Transactions of the Royal Society of Edinburgh 100, 219-33.

Spalla, M. I., Gosso, G., Marotta, A. M., Zucali, M. \& SALVI, F. 2010. Analysis of natural tectonic systems coupled with numerical modelling of the polycyclic continental lithosphere of the Alps. International Geology Review 52, 1268-302.

Spalla, M. I. \& MAROTTA, A. M. 2007. P-T evolutions vs. numerical modelling: a key to unravel the Paleozoic to early-Mesozoic tectonic evolution of the Alpine area. Periodico di Mineralogia 76, 267-308.

Spalla, M. I., Siletto, G. B., Di Paola, S. \& Gosso, G. 2000. The role of structural and metamorphic memory in the distinction of tectono-metamorphic units: the basement of the Como lake in the Southern Alps. Journal of Geodynamics 30, 191-204.

Spalla, M. I., Zucali, M., Di PaOla, S. \& Gosso, G. 2005. A critical assessment of the tectono-thermal memory of rocks and definition of tectono-metamorphic units: evidence from fabric and degree of metamorphic transformations. In Deformation Mechanisms, Rheology and Tectonics: From Minerals to the Lithosphere (eds D. Gapais, J. P. Brun \& P. R. Cobbold), pp. 227-47. Geological Society of London, Special Publication no. 243.

Spear, F. S. \& Cheney, J. T. 1989. A petrogenetic grid for pelitic schists in the system $\mathrm{SiO}_{2}-\mathrm{Al}_{2} \mathrm{O}_{3}-\mathrm{FeO}-\mathrm{MgO}$ $\mathrm{K}_{2} \mathrm{O}-\mathrm{H}_{2} \mathrm{O}$. Contributions to Mineralogy and Petrology 101, 149-64.

Thoni, M. \& Miller, C. 2000. Permo-Triassic pegmatites in the eo-Alpine eclogite-facies Koralpe complex, Austria: age and magma source constraints from mineral chemical, $\mathrm{Rb}-\mathrm{Sr}$ and $\mathrm{Sm}-\mathrm{Nd}$ isotope data. Schweizerische Mineralogische und Petrographische Mitteilungen 80, 169-86.

TURNER, F. J. \& WeISS, L. E. (eds). 1963. Structural Analysis of Metamorphic Tectonites. New York: MacGraw-Hill.

VAVRA, G., SCHMID, R. \& GeBAUER, D. 1999. Internal morphology, habit and $\mathrm{U}-\mathrm{Th}-\mathrm{Pb}$ microanalysis of amphibolite-to-granulite facies zircons: geochronology of the Ivrea Zone (Southern Alps). Contributions to Mineralogy and Petrology 134, 380-404.

Vernon, H. V. (ed). 2004. A Practical Guide to Rock Microstructure. Cambridge: Cambridge University Press.

Vernon, R. \& Clarke, G. 2008. Principles of Metamorphic Petrology. Cambridge: Cambridge University Press.

von Raumer, J. F., Stampfli, G. A. \& Bussy, F. 2003. Gondwana-derived microcontinents - the constituents 
of the Variscan and Alpine collisional orogens. Tectonophysics $\mathbf{3 6 5}, 7-22$.

WeBer, K. 1984. Variscan events: early Palaeozoic continental rift metamorphism and late Palaeozoic crustal shortening. In Variscan Tectonics of the North Atlantic Region (eds d. H. W. Hutton \& D. J. Sanderson), pp. 3 23. Geological Society of London, Special Publication no. 14.

White, R. W. \& Powell, R. 2002. Melt loss and the preservation of granulite facies mineral assemblages. Journal of Metamorphic Geology 20, 621-32.

White, R. W., Powell, R. \& Holland, J. B. 2001. Calculation of partial melting equilibria in the system $\mathrm{Na}_{2} \mathrm{O}-\mathrm{CaO}-\mathrm{K}_{2} \mathrm{O}-\mathrm{FeO}-\mathrm{MgO}-\mathrm{Al}_{2} \mathrm{O}_{3}-\mathrm{SiO}_{2}$ (NCKFMASH). Journal of Metamorphic Geology 19, 139-53.

Whitney, D. L. \& Evans, B. W. 2010. Abbreviation for names of rock-forming minerals. American Mineralogist 95, 185-87.
WU, C. \& ChenG, B. 2006. Valid garnet-biotite (GB) geothermometry and garnet-aluminum silicate-plagioclasequartz (GASP) geobarometry in metapelitic rocks. Lithos 89, 1-23.

ZUCALI, M. 2005. JPT-Mineral formula calculation and geothermobarometry. http://users.unimi.it/mzucali/dev/ java/JPT.htm

ZUCALI, M. 2011. Coronitic microstructures in patchy eclogitised continental crust: the Lago della Vecchia preAlpine metagranite (Sesia-Lanzo Zone, Western Italian Alps). In The Science of Microstructure - Part II (eds M. A. Forster \& J. D. Fitz Gerald). Journal of the Virtual Explorer 38, paper 5.

Zucali, M., Manzotti, P., Diella, V., Pesenti, C., Risplendente, A., Darling, J. \& Engi, M. 2011. Permian tectonometamorphic evolution of the Dent Blanche Unit (Austroalpine domain, Western Italian Alps). Rendiconti Online Società Geologica Italiana 15, 133-36. 